\title{
9. PETROLOGY OF SELECTED LEG 147 BASALTIC LAVAS AND DIKES ${ }^{1}$
}

\author{
James F. Allan, ${ }^{2}$ Trevor Falloon, ${ }^{3}$ Rolf B. Pedersen, ${ }^{4}$ B. Shankar Lakkapragada, ${ }^{2}$ James H. Natland,,${ }^{5}$ and John Malpas ${ }^{6}$
}

\begin{abstract}
Sites 894 and 895 of Ocean Drilling Program Leg 147 recovered a variety of basaltic material from the Hess Deep intrarift ridge, including cores of dikes that cut gabbroic and peridotitic wall rock and fragments of pillowed, surficial lava flows. Site 894 samples include highly primitive plagioclase, olivine, and $\mathrm{Cr}$-spinel phyric basaltic dikes, with melt $\mathrm{Mg} /\left(\mathrm{Mg}+\mathrm{Fe}^{2+}\right)(\mathrm{Mg} \#)$

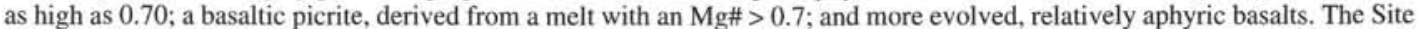
894 basalts are more depleted than East Pacific Rise (EPR) N-MORB in incompatible elements, with extreme depletions in both the light rare earth elements (LREE) and $\mathrm{Ta}$ and $\mathrm{Nb}$. These depletions are illustrated by their chondrite-normalized $\mathrm{La} / \mathrm{Sm}$ and $\mathrm{Ta} / \mathrm{Hf}$ ratios, which vary from 0.30 to 0.51 and from 0.12 to 0.28 , respectively, and demand an unusually depleted mantle source. The intrusive relations, mineralogy, and geochemistry of these samples support an off-axis origin of these samples during opening of the Hess Deep.

The Site 895 basalts, sampled from both dikes and pillowed flows, are aphyric and more evolved and less depleted in LREE and $\mathrm{Ta}$ and $\mathrm{Nb}$ than the Site 894 samples, with $(\mathrm{La} / \mathrm{Sm})_{\mathrm{N}}$ and $(\mathrm{Ta} / \mathrm{Hf})_{\mathrm{N}}$ ratios varying from 0.60 to 0.71 and from 0.46 to 0.53 , respectively. Unlike the Site 894 samples, these characteristics allow derivation from a mantle similar in composition to that underlying the EPR. Intrusive relations and geochemical characteristics support a mixed origin for the Site 895 samples, with some originating at or near the EPR ridge crest, and others representing volcanism associated with Hess Deep opening.
\end{abstract}

\section{INTRODUCTION}

Leg 147 of the Ocean Drilling Program was the first leg to use the "offset-drilling" approach, that is, coring holes at various locations within tectonic exposures of ocean crust and upper mantle to create composite stratigraphic sections. As such, the primary goals were to obtain continuous sections of mid-crustal gabbro (at Site 894; Fig. 1) and melt-impregnated, uppermost mantle (at Site 895). These sites are located respectively on the top and upper flank of an uplifted, tilted fault block (the intrarift ridge) within the Hess Deep, a deep tectonic gore at the tip of the westward-propagating Cocos-Nazca spreading center that cuts 0.5 - to 1.0-Ma crust that formed at the adjacent East Pacific Rise (EPR) (Lonsdale, 1988; Francheteau et al., 1990; Gillis, Mével, Allan, et al., 1993). Presumably, the cored gabbroic sections at Site 894 crystallized underneath the adjacent EPR during crustal formation, as did the melt impregnations of the Site 895 peridotites, now represented by gabbroic segregations (Gillis, Mével, Allan, et al., 1993; Allan and Dick, this volume).

In addition to the gabbroic and peridotite rocks recovered, two varieties of basaltic rocks were recovered: core derived from dikes, and small, often thumbnail-sized accidental fragments of pillow lava flows in surficial breccias and turbiditic sediments. The proximity of these basaltic rocks to the recovered sections, with the dikes crosscutting the gabbroic and peridotite sections, raises important questions as to their genesis. In particular, a major question regards whether the dikes are part of the same magmatic sequences that produced the Site

'Mével, C., Gillis, K.M., Allan, J.F., and Meyer, P.S. (Eds.), 1996. Proc. ODP, Sci. Results, 147: College Station, TX (Ocean Drilling Program).

${ }^{2}$ Ocean Drilling Program and Department of Geology. Texas A\&M University, College Station, TX 77845, U.S.A. Allan: Jamie_Allan@odp.tamu.edu

'Department of Geology. University of Tasmania, GPO Box 252C, 7001 Hobart, Tasmania, Australia.T.J.FALLOON@UK.AC.BRISTOL

${ }^{4}$ Geological Institute, University of Bergen, Allégt. 41, N-5007 Bergen, Norway.

${ }^{5}$ Rosenstiel School of Marine and Atmospheric Sciences, 4600 Rickenbacker Causeway, University of Miami, Miami, FL 33149, U.S.A. jnatland@umigw.miami.edu

'Department of Earth Sciences, Memorial University of Newfoundland, St. John's, Newfoundland A1B 3X5, Canada. odp@ kean.ucs.mun.ca
894 gabbros and the Site 895 gabbroic melt impregnations. Namely, do the dikes represent ridge-crest magmatism, or do they represent later magmatism perhaps associated with the formation of the Hess Deep? Similar questions surround the origin of the basaltic lava fragments, as their accidental nature of recovery from directly on top of gabbro and peridotite does not allow the absolute determination of whether they represent fragments of flows emplaced nearby or whether they are sedimentary relicts predating the uplift of the intrarift ridge.

This paper represents a compilation of the geochemical and mineralogical data that we have collected that bear on these problems of origin. Pedersen et al. (this volume) also present additional isotopic data for the Site 894 basaltic dikes. The dataset presented here is of a necessarily fragmentary nature, because of the small size of many of the lava samples. Nevertheless, we will show that the data are inconsistent with a simple cogenetic origin of the basaltic and gabbroic samples as well as that the Site 894 samples probably represent offaxis volcanism associated with the opening of the Hess Deep.

\section{ANALYTICAL METHODS}

Electron microprobe (EMP), X-ray fluorescence (XRF), instrumental neutron activation (INA), and inductively coupled plasmamass spectrometry (ICP-MS) analyses are presented in this study. The EMP analyses were made on a Cameca SX-50 microprobe using natural (Jarosewich et al., 1980) and synthetic standards, with mineral analyses (Tables 1-4) using a focused beam, sample currents of $10-30$ nanoamps, and counting times of $10-180 \mathrm{~s}$. The EMP glass analyses (Table 5) were made using a 10- $\mu \mathrm{m}$ beam, a sample current of 10 nanoamps, and counting times of $30-60 \mathrm{~s}$. These analyses should closely approximate erupted magma compositions (Byerly et al., 1976). The INA, ICP-MS, and XRF analyses (Tables 6-8) were obtained either from splits of whole-rock powders crushed on ship in agate and later analyzed by X-ray fluorescence (XRF) (Gillis, Mével, Allan, et al., 1993), or from powders obtained on shore by crushing whole-rock samples in agate or Al-ceramic grinding vessels. 


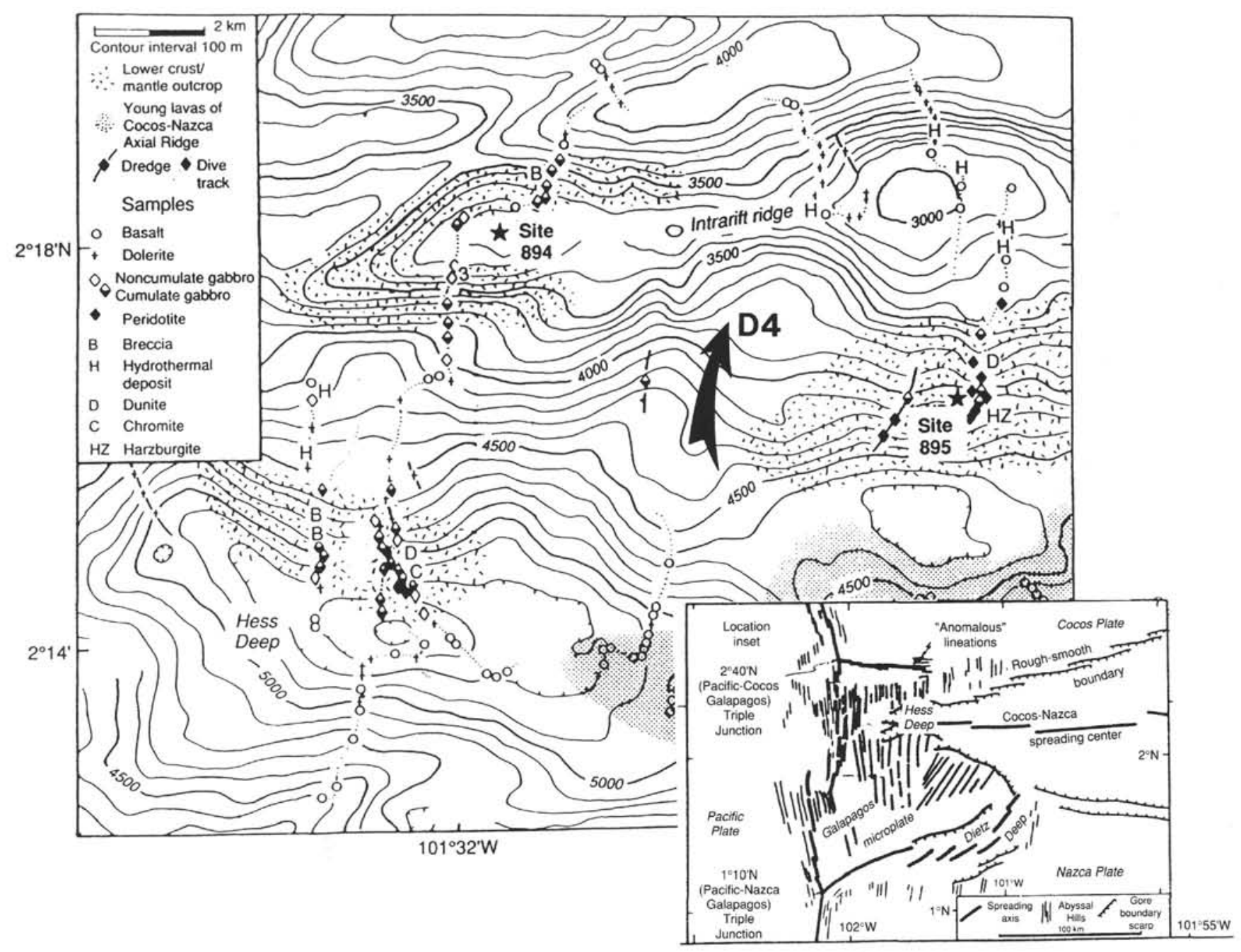

Figure 1. Location map of Hess Deep sites cored during Leg 147 (from Gillis, Mével, Allan, et al., 1994, modified from Francheteau et al., 1990; inset modified from Lonsdale et al., 1992). Arrow shows location of Dredge D4 on the intrarift ridge (Nilsson, 1993), which collected fresh, glassy basalts erupted onto peridotite and gabbro.

The INA analyses were obtained at Texas A\&M University using an on-campus TRIGA reactor for irradiation and counting facilities in the Center for Chemical Characterization for analysis. Detailed descriptions of analytical procedures are given in Hawkins and Allan (1994) and Allan (in press). Samples of 150-200 mg were irradiated for $14 \mathrm{hr}$ and counted for $6 \mathrm{hr}$ apiece at $9-12$ and $40-43$ days. To ensure historical run-to-run consistency, a sample of the international standard BHVO was run in each layer, with results given in Table 7. These results show excellent overall agreement with accepted values (Gladney et al., 1983).

The ICP-MS data were obtained at the University of Bristol, analyzing 200-mg samples of rock powder digested in Aristar grade hydroflouric and nitric acid. The XRF spectrometry data were obtained on a Philips PW1404 from rock powder using glass beads for major element analysis and pressed powder pellets for trace elements. International standards and the recommended values of Govindaraju (1984) were used for calibration. Further analytical details for both the ICP-MS and XRF methods are given in Pedersen et al. (this volume).

\section{PETROGRAPHY AND MINERAL CHEMISTRY}

Several samples from Site 894 were selected for EMP investigation of mineral chemistry and are described here in greater detail.
ODP conventions (Gillis, Mével, Allan, et al., 1993) are followed regarding sample identification (leg, core, core type, section, interval) and alteration terminology (fresh $=0 \%-2 \%$, slight $=2 \%-10 \%$, moderate $=10 \%-40 \%$, and high $=40 \%-80 \%$ ). Phenocrysts, microphenocrysts, and groundmass grains are defined as $>0.5 \mathrm{~mm}, 0.25-0.5$ $\mathrm{mm}$, and $<0.25 \mathrm{~mm}$, respectively (Allan et al., 1989). Quenched textural terms (such as spherulitic and microlitic) follow Natland et al. (1983) and Allan et al. (1989).

\section{Site 894}

\section{Hole 894D}

Samples 147-894D-1R-1, 106-109 cm, and 1R-CC, 2-4 cm, are fresh, dense, unoriented small fragments of aphyric pillow basalt. Mineral phases in quench glass and the glass itself were analyzed on the EMP (Tables 2,3,5). They contain $<1 \%$ lathlike, stubby, or elongate skeletal plagioclase phenocrysts (up to $1.5 \mathrm{~mm} ; \mathrm{An}_{72-75}$ in composition), commonly intergrown with subordinate, euhedral to skeletal olivine (up to $1 \mathrm{~mm} ; \mathrm{Fo}_{85-86}$ in composition) in a microlitic to glassy groundmass. Clinopyroxene and oxides are absent.

Sample 147-894D-1R-CC, 4-6 cm, is very different, representing a highly olivine and $\mathrm{Cr}$-spinel phyric basalt (Pl. 1A). The abundance of large (up to $6 \mathrm{~mm}$ ), slightly rounded olivine phenocrysts (about $25 \%-30 \%$ of the rock) indicates that this sample represents a picrite 
Table 1. Representative Cr-spinel analyses, Holes 894G and 894D.

\begin{tabular}{|c|c|c|c|c|c|c|c|c|c|c|c|c|c|c|c|c|c|c|c|c|}
\hline Hole: & $894 \mathrm{G}$ & $894 \mathrm{G}$ & $894 \mathrm{G}$ & $894 \mathrm{G}$ & $894 \mathrm{G}$ & $894 \mathrm{G}$ & $894 \mathrm{G}$ & $894 \mathrm{G}$ & $894 \mathrm{G}$ & $894 \mathrm{G}$ & $894 \mathrm{G}$ & 894D & 894D & 894D & 894D & 894D & 894D & 894D & 894D & 894D \\
\hline Core, section & $19 \mathrm{R}-1$ & $19 \mathrm{R}-1$ & $19 R-1$ & $19 \mathrm{R}-1$ & $19 \mathrm{R}-1$ & $2 \mathrm{R}-2$ & $2 \mathrm{R}-2$ & $2 \mathrm{R}-2$ & $2 R-1$ & $2 \mathrm{R}-1$ & $2 R-1$ & IR-CC & IR-CC & IR-CC & IR-CC & IR-CC & IR-CC & IR-CC & IR-CC & IR-CC \\
\hline Interval $(\mathrm{cm})$ : & $77-79$ & 77-79 & $77-79$ & $77-79$ & 77-79 & $104-105$ & 104-105 & $104-105$ & $24-26$ & $68-71$ & $68-71$ & $4-6$ & $4-6$ & $4-6$ & $4-6$ & $4-6$ & $4-6$ & $4-6$ & $4-6$ & $4-6$ \\
\hline Analysis no.: & IGC & $7 \mathrm{GC}$ & 9GR & $10 \mathrm{MC}$ & $12 \mathrm{MR}$ & $1 \mathrm{GC}$ & $4 \mathrm{GC}$ & $5 \mathrm{GR}$ & $5 \mathrm{MC}$ & $1 \mathrm{MC}$ & $6 \mathrm{MC}$ & A PC & A PR & D PC & D PR & 6INR & 7INC & $9 \mathrm{GC}$ & $\mathrm{C} M \mathrm{C}$ & $12 \mathrm{GC}$ \\
\hline $\mathrm{SiO}_{2}$ & 0.09 & $\begin{array}{l}0.17 \\
0.37\end{array}$ & 0.04 & 0.06 & 0.06 & 0.13 & 0.12 & 0.06 & 0.12 & 0.04 & 0.01 & 0.04 & 0.11 & 0.08 & 0.10 & 0.10 & 0.09 & 0.10 & 0.05 & 0.07 \\
\hline $\mathrm{TiO}_{2}^{2}$ & $\begin{array}{r}0.29 \\
4076\end{array}$ & $\begin{array}{r}0.37 \\
31.71\end{array}$ & & $\begin{array}{r}0.28 \\
3072\end{array}$ & $\begin{array}{r}0.28 \\
426.2\end{array}$ & $\begin{array}{r}0.25 \\
42.38\end{array}$ & 0.22 & 14.94 & 0.34 & $\begin{array}{r}0.35 \\
3807\end{array}$ & 0.45 & 0.27 & $\begin{array}{r}0.31 \\
35.75\end{array}$ & 0.23 & 0.23 & 0.26 & 0.26 & 0.25 & 0.23 & $\begin{array}{r}0.31 \\
37.72\end{array}$ \\
\hline $\mathrm{Al}_{2} \mathrm{O}_{3}$ & $\begin{array}{l}40.76 \\
0.13\end{array}$ & $\begin{array}{r}31.71 \\
0.15\end{array}$ & $\begin{array}{r}34.18 \\
0.13\end{array}$ & 39.72 & 42.62 & 42.38 & 49.05 & 2.67 & $\begin{array}{l}37.95 \\
0.17\end{array}$ & 38.07 & 30.43 & 35.14 & 35.75 & 42.20 & 41.03 & 41.00 & 39.78 & 41.41 & 38.91 & $\begin{array}{r}37.72 \\
0.17\end{array}$ \\
\hline $\mathrm{V}_{2} \mathrm{O}_{3}$ & 0.13 & 0.15 & 0.13 & 0.13 & 0.13 & 0.11 & 0.12 & 0.51 & 0.17 & 0.15 & 0.17 & 0.11 & 0.11 & 0.12 & 0.09 & 0.10 & 0.13 & 0.07 & 0.11 & $\begin{array}{r}0.17 \\
27.92\end{array}$ \\
\hline $\mathrm{Cr}_{2} \mathrm{O}_{3}$ & 25.58 & 34.49 & 31.62 & 27.62 & 23.75 & 24.06 & 16.65 & 12.84 & 28.51 & 28.09 & 35.02 & 32.31 & 29.75 & 24.80 & 25.17 & 25.78 & 27.39 & 25.80 & 28.34 & $\begin{array}{l}27.92 \\
15.72\end{array}$ \\
\hline $\mathrm{FeO}$ & 14.07 & 15.76 & 15.78 & 13.61 & 13.93 & 13.53 & 13.02 & 63.03 & 14.20 & 14.50 & 16.36 & 13.43 & 15.11 & 12.71 & 13.81 & 12.65 & 12.44 & 12.75 & 12.75 & $\begin{array}{r}15.72 \\
0.33\end{array}$ \\
\hline $\mathrm{MnO}$ & 0.12 & 0.10 & 0.14 & 0.08 & 0.11 & 0.10 & 0.14 & 1.85 & 0.12 & 0.20 & 0.17 & 0.34 & 0.43 & 0.36 & 0.34 & 0.30 & 0.36 & 0.33 & 0.35 & 0.33 \\
\hline $\mathrm{NiO}$ & 0.24 & 0.18 & 0.21 & 0.27 & 0.30 & 0.25 & 0.30 & 0.04 & 0.25 & 0.28 & 0.17 & 0.18 & 0.21 & 0.30 & 0.33 & 0.27 & 0.29 & 0.29 & 0.26 & 0.20 \\
\hline $\mathrm{ZnO}$ & 0.01 & 0.08 & 0.03 & 0.06 & 0.05 & 0.09 & 0.05 & 0.20 & 0.00 & 0.06 & 0.10 & 0.10 & 0.04 & 0.05 & 0.04 & 0.11 & 0.07 & 0.02 & 0.00 & 0.03 \\
\hline $\mathrm{MgO}$ & 18.53 & 16.64 & 17.06 & 18.27 & 18.24 & 18.57 & 19.53 & 0.48 & 17.92 & 17.95 & 16.60 & 18.06 & 17.38 & 19.25 & 18.84 & 19.10 & 19.21 & 18.99 & 18.61 & 17.43 \\
\hline $\mathrm{CaO}$ & & & 0.05 & & & 0.03 & & 0.19 & 0.01 & 0.00 & 0.00 & 0.03 & & 0.00 & 0.06 & 0.00 & 0.01 & 0.00 & 0.00 & 0.05 \\
\hline Total & 99.85 & 99.72 & 99.61 & 100.10 & 99.57 & 99.51 & 99.22 & 96.81 & 99.60 & 99.69 & 99.48 & 100.01 & 99.29 & 100.10 & 100.04 & 99.67 & 100.03 & 100.01 & 99.61 & 99.95 \\
\hline $\mathrm{RFeO}$ & 10.17 & 11.73 & 11.28 & 10.42 & 10.58 & $\begin{array}{r}10.19 \\
3.70\end{array}$ & 9.59 & 42.36 & 10.67 & $\begin{array}{l}10.43 \\
.5 ?\end{array}$ & 11.39 & 9.71 & 10.62 & 8.99 & $\begin{array}{l}9.38 \\
4.92\end{array}$ & $\begin{array}{l}8.98 \\
4.08\end{array}$ & $\begin{array}{l}8.67 \\
4.19\end{array}$ & 9.34 & $\begin{array}{l}9.34 \\
3.79\end{array}$ & $\begin{array}{r}11.18 \\
504\end{array}$ \\
\hline $\mathrm{Fe}_{2}$ & 34.34 & 4. & 5. & 3. & 3.72 & 3.7 & 3. & 22. & 3.92 & 4.52 & 5.52 & 4.1 & 4. & 4.14 & 4.92 & 4.08 & 4. & 3. & 3.79 & $\begin{array}{r}5.04 \\
100.46\end{array}$ \\
\hline Total & 100.29 & 100.17 & 100.11 & 100.46 & 99.94 & 99.88 & 99.60 & 99.11 & 99.99 & 100.14 & 100.04 & 100.42 & 99.79 & 100.51 & 100.53 & 100.08 & 100.45 & 100.39 & 99.99 & 100.46 \\
\hline Fe\# & 0.046 & 0.050 & 0.054 & 0.037 & 0.039 & 0.039 & 0.039 & 0.565 & 0.042 & 0.048 & 0.061 & 0.044 & 0.054 & 0.043 & 0.051 & 0.043 & 0.044 & 0.040 & 0.040 & $\begin{array}{l}0.054 \\
0.314\end{array}$ \\
\hline & & & & & & & & & & & & & & & & & & & 0.315 & $\begin{array}{l}0.314 \\
0.332\end{array}$ \\
\hline Cr\# & 296 & 0.422 & 0.38 & $\begin{array}{l}0.318 \\
0.750\end{array}$ & 0.272 & 0,760 & 0.185 & & 0.3 & 0.331 & 0.4 & 0.3 & & 0.283 & 0.291 & 0.29 & 0.3 & 0.295 & 0.328 & $\begin{array}{l}0.332 \\
0.735\end{array}$ \\
\hline Mg\# & 0.765 & 0.717 & 0.729 & 0.758 & 0.754 & 0.765 & 0.784 & 0.020 & 0.750 & 0.754 & 0.722 & 0.768 & 0.745 & 0.792 & 0.782 & 0.791 & 0.798 & 0.784 & 0.780 & \\
\hline Melt $N$ & & & & & & & & & & & & & & & 069 & & & & 069 & \\
\hline $\begin{array}{l}\mathrm{Kd} 3.14 \\
\mathrm{Kd} 2.83\end{array}$ & $\begin{array}{l}0.66 \\
0.69\end{array}$ & $\begin{array}{l}0.68 \\
0.68\end{array}$ & $\begin{array}{l}.65 \\
0.68\end{array}$ & $\begin{array}{l}0.66 \\
0.68\end{array}$ & 0.64 & $\begin{array}{l}0.65 \\
0.68\end{array}$ & $\begin{array}{l}0.65 \\
0.67\end{array}$ & & $\begin{array}{l}.66 \\
0.68\end{array}$ & $\begin{array}{l}0.66 \\
0.69\end{array}$ & $\begin{array}{l}0.67 \\
0.69\end{array}$ & $\begin{array}{l}0.70 \\
0.72\end{array}$ & $\begin{array}{l}0.67 \\
0.69\end{array}$ & 0.72 & $\begin{array}{l}0.69 \\
0.71\end{array}$ & $\begin{array}{l}0.70 \\
0.72\end{array}$ & 0.73 & $\begin{array}{l}0.79 \\
0.71\end{array}$ & 0.71 & $\begin{array}{l}0.65 \\
0.67\end{array}$ \\
\hline
\end{tabular}

Notes: Analysis by electron microprobe ( $\mathrm{J}$. Allan, analyst). Analyses are recalculated by stoichiometry according to the methods of $\mathrm{Carmichael}(1967), \mathrm{Mg} \#=\mathrm{Mg} /\left(\mathrm{Mg}+\mathrm{Fe}{ }^{2+}\right), \mathrm{Cr} \#=\mathrm{Cr} /\left(\mathrm{Cr}+\mathrm{Al}+\mathrm{Fe}{ }^{3+}\right)$, and $\mathrm{Fe} \#=\mathrm{Fe}{ }^{3+} /\left(\mathrm{Cr}+\mathrm{Al}+\mathrm{Fe}{ }^{3+}\right)$. The size nomenclature follows that of Batiza and Vanko (1984) and Allan et al. (1987). Crystals $>0.5 \mathrm{~mm}=$ phenocrysts ( $\mathrm{P}$ ), crystals $0.5-0.25 \mathrm{~mm}$ in size $=$ microphenocrysts $(\mathrm{M})$, and crystals $<0.25 \mathrm{~mm}=$ groundmass crystals $(\mathrm{G})$. In addition, $\mathrm{C}=$ core, $\mathrm{R}=$ rim, and $\mathrm{I}=$ inclusion, with I denoting inclusion in olivine. Predicted liquid $\mathrm{Mg} \#$ represents calculated equilibrium silicate liquid $\mathrm{Mg} /\left(\mathrm{Mg}+\mathrm{Fe}{ }^{2+}\right.$ ) based upon methods of Allan (1992), using given assumed olivineliquid distribution coefficients as discussed in text.

Table 2. Representative olivine analyses, Holes 894G and 894D.

\begin{tabular}{|c|c|c|c|c|c|c|c|c|c|c|c|c|c|c|c|c|c|c|c|c|}
\hline Hole: & $894 \mathrm{G}$ & $894 \mathrm{G}$ & $894 \mathrm{G}$ & $894 \mathrm{G}$ & $894 \mathrm{G}$ & $894 \mathrm{G}$ & $894 \mathrm{G}$ & $894 \mathrm{G}$ & 894D & 894D & 894D & 894D & $894 \mathrm{D}$ & 894D & 894D & 894D & $894 \mathrm{D}$ & 894D & 894D & 894D \\
\hline Core, section: & $2 \mathrm{R}-2$ & $2 \mathrm{R}-2$ & $2 R-2$ & $2 \mathrm{R}-2$ & $2 \mathrm{R}-1$ & $2 \mathrm{R}-1$ & $2 \mathrm{R}-1$ & $2 \mathrm{R}-1$ & IR-CC & IR-CC & IR-CC & IR-CC & IR-CC & IR-CC & IR-CC & IR-CC & IR-CC & IR-CC & IR-CC & IR-CC \\
\hline Interval $(\mathrm{cm})$ : & $104-105$ & $104-105$ & $104-105$ & $104-105$ & $68-71$ & $68-71$ & $68-71$ & $68-71$ & $4-6$ & $4-6$ & $4-6$ & $4-6$ & 46 & $4-6$ & $4-6$ & $4-6$ & $2-4$ & $2-4$ & $2-4$ & $2-4$ \\
\hline Analysis no.: & I PC & $3 \mathrm{PR}$ & $4 \mathrm{PC}$ & $6 \mathrm{PR}$ & $3 \mathrm{PC}$ & $4 \mathrm{PR}$ & $6 \mathrm{PC}$ & $8 \mathrm{PR}$ & $\mathrm{CIPC}$ & $\mathrm{C} 2 \mathrm{PC}$ & $1 \mathrm{PC}$ & $2 \mathrm{PR}$ & DI PC & DI PR & $3 G$ & $6 \mathrm{G}$ & $1 \mathrm{GC}$ & $2 \mathrm{GR}$ & $6 \mathrm{G}$ & $7 \mathrm{G}$ \\
\hline Total & $\begin{array}{r}0.17 \\
0.28 \\
47.54 \\
0.29 \\
99.48\end{array}$ & $\begin{array}{r}40.40 \\
11.89 \\
0.15 \\
0.28 \\
47.46 \\
0.31 \\
100.48\end{array}$ & $\begin{array}{r}0.29 \\
99.97\end{array}$ & $\begin{array}{r}0.16 \\
0.26 \\
47.70 \\
0.28 \\
100.28\end{array}$ & $\begin{array}{r}0.16 \\
0.22 \\
47.78 \\
0.28 \\
99.81\end{array}$ & $\begin{array}{r}0.28 \\
0.10 \\
37.96 \\
0.29 \\
99.40\end{array}$ & $\begin{array}{r}0.17 \\
0.23 \\
47.45 \\
0.31 \\
99.97\end{array}$ & $\begin{array}{r}0.18 \\
0.29 \\
47.26 \\
0.33 \\
99.79\end{array}$ & $\begin{array}{r}40.31 \\
9.86 \\
0.15 \\
0.29 \\
49.03 \\
0.27 \\
99.91\end{array}$ & $\begin{array}{r}40.47 \\
9.49 \\
0.15 \\
0.41 \\
49.28 \\
0.27 \\
100.07\end{array}$ & $\begin{array}{r}40.37 \\
9.99 \\
0.12 \\
0.37 \\
48.95 \\
0.26 \\
100.07\end{array}$ & $\begin{array}{r}0.23 \\
0.09 \\
44.14 \\
0.32 \\
99.97\end{array}$ & $\begin{array}{r}40.48 \\
9.75 \\
0.16 \\
0.30 \\
49.04 \\
0.27 \\
99.99\end{array}$ & $\begin{array}{r}0.29 \\
99.51\end{array}$ & $\begin{array}{r}0.20 \\
0.14 \\
45.20 \\
0.38 \\
99.50\end{array}$ & $\begin{array}{r}0.19 \\
0.23 \\
47.01 \\
0.31 \\
99.87\end{array}$ & $\begin{array}{r}45.92 \\
0.30 \\
99.79\end{array}$ & $\begin{array}{r}45.41 \\
0.33 \\
99.61\end{array}$ & $\begin{array}{r}39.55 \\
14.42 \\
0.27 \\
0.16 \\
45.51 \\
0.32 \\
100.23\end{array}$ & $\begin{array}{r}39.56 \\
14.20 \\
0.20 \\
0.12 \\
45.47 \\
0.32 \\
99.87\end{array}$ \\
\hline $\begin{array}{l}\text { Fo } \\
\text { Melt N }\end{array}$ & 0.884 & 0.877 & 0.877 & 0.879 & 0.884 & 0.747 & 0.878 & 0.875 & 0.899 & 0.902 & 0.897 & 0.833 & 0.900 & 0.886 & 0.852 & 0.873 & 0.859 & 0.853 & 0.849 & 0.851 \\
\hline $\begin{array}{l}0.3 \mathrm{Kd} \\
0.27 \mathrm{Kd}\end{array}$ & $\begin{array}{l}0.696 \\
0.673\end{array}$ & $\begin{array}{l}0.681 \\
0.658\end{array}$ & $\begin{array}{l}0.682 \\
0.659\end{array}$ & $\begin{array}{l}0.686 \\
0.663\end{array}$ & $\begin{array}{l}0.695 \\
0.673\end{array}$ & $\begin{array}{l}0.469 \\
0.443\end{array}$ & $\begin{array}{l}0.684 \\
0.661\end{array}$ & $\begin{array}{l}0.678 \\
0.655\end{array}$ & $\begin{array}{l}0.727 \\
0.705\end{array}$ & $\begin{array}{l}0.735 \\
0.714\end{array}$ & $\begin{array}{l}0.724 \\
0.702\end{array}$ & $\begin{array}{l}0.599 \\
0.573\end{array}$ & $\begin{array}{l}0.729 \\
0.708\end{array}$ & $\begin{array}{l}0.700 \\
0.677\end{array}$ & $\begin{array}{l}0.633 \\
0.608\end{array}$ & $\begin{array}{l}0.673 \\
0.649\end{array}$ & $\begin{array}{l}0.647 \\
0.622\end{array}$ & $\begin{array}{l}0.636 \\
0.611\end{array}$ & $\begin{array}{l}0.628 \\
0.603\end{array}$ & $\begin{array}{l}0.631 \\
0.606\end{array}$ \\
\hline
\end{tabular}

Notes: Analysis by electron microprobe ( $\mathrm{J}$. Allan, analyst). $\mathrm{P}=$ phenocrysts, $\mathrm{M}=$ microphenocrysts, and $\mathrm{G}=$ groundmass-sized crystals (although " $\mathrm{G}$ " can also represent crystals in glass). $\mathrm{C}=$ core and $\mathrm{R}=$ rim. Fo $=$ olivine forsterite content. Predicted liquid $\mathrm{Mg} \#$ represents calculated equilibrium silicate liquid $\mathrm{Mg} /\left(\mathrm{Mg}+\mathrm{Fe}{ }^{2+}\right)$ based upon methods of Roeder and Emslie (1970) using olivine-silicate liquid $\mathrm{K}_{\mathrm{D}} \mathrm{s}$ of 0.27 and 0.3 as discussed in text. 
Table 3. Representative plagioclase analyses, Holes 894D and 894G.

\begin{tabular}{|c|c|c|c|c|c|c|c|c|c|c|c|c|c|c|c|}
\hline Hole: & 894D & $894 \mathrm{D}$ & 894D & 894D & $894 \mathrm{D}$ & $894 \mathrm{G}$ & $894 \mathrm{G}$ & $894 \mathrm{G}$ & $894 \mathrm{G}$ & $894 G$ & $894 \mathrm{G}$ & $894 \mathrm{G}$ & $894 \mathrm{G}$ & $894 \mathrm{G}$ & $894 \mathrm{G}$ \\
\hline Core, section: & IR-CC & IR-CC & IR-CC & IR-CC & IR-CC & $2 \mathrm{R}-1$ & $2 \mathrm{R}-1$ & $2 R-1$ & $2 \mathrm{R}-1$ & $2 \mathrm{R}-1$ & $2 \mathrm{R}-1$ & $2 \mathrm{R}-1$ & $2 \mathrm{R}-2$ & $2 \mathrm{R}-2$ & $2 \mathrm{R}-2$ \\
\hline Interval $(\mathrm{cm})$ : & $2-4$ & $2-4$ & $2-4$ & $4-6$ & $4-6$ & $68-71$ & $68-71$ & $68-71$ & $24-26$ & $24-26$ & $24-26$ & $24-26$ & $73-75$ & $73-75$ & $73-75$ \\
\hline Analysis no:: & $4 \mathrm{GC}$ & $5 \mathrm{GR}$ & $8 \mathrm{G}$ & $2 \mathrm{GR}$ & $3 \mathrm{G}$ & $2 \mathrm{G}$ & DI PC & $5 \mathrm{G}$ & P1 PC & P2 PC & P3 PC & P4 PC & $\mathrm{C} 1 \mathrm{PC}$ & $4 \mathrm{GC}$ & $5 \mathrm{GR}$ \\
\hline $\mathrm{SiO}_{2}$ & 47.39 & 51.81 & 49.96 & 50.13 & 49.63 & 52.31 & 46.56 & 49.31 & 46.01 & 49.15 & 50.20 & 45.92 & 47.65 & 49.09 & 55.16 \\
\hline $\mathrm{Al}_{2} \mathrm{O}_{3}$ & 33.78 & 30.29 & 31.53 & 31.64 & 32.29 & 29.70 & 34.04 & 32.20 & 34.51 & 32.70 & 31.95 & 34.72 & 33.36 & 32.53 & 27.89 \\
\hline $\mathrm{FeO}$ & 0.36 & 1.12 & 0.73 & 0.64 & 0.75 & 0.72 & 0.35 & 0.46 & 0.32 & 0.44 & 0.47 & 0.21 & 0.43 & 0.44 & 0.90 \\
\hline $\mathrm{MgO}$ & 0.25 & 0.38 & 0.34 & 0.29 & 0.29 & 0.23 & 0.21 & 0.23 & 0.19 & 0.31 & 0.30 & 0.16 & 0.25 & 0.22 & 0.11 \\
\hline $\mathrm{CaO}$ & 16.78 & 13.93 & 14.69 & 14.73 & 15.29 & 12.51 & 17.22 & 15.02 & 17.49 & 15.24 & 14.52 & 17.66 & 16.26 & 15.38 & 10.53 \\
\hline $\mathrm{N}_{2} \mathrm{O}$ & 1.95 & 3.51 & 2.97 & 3.07 & 2.79 & 4.32 & 1.61 & 2.73 & 1.44 & 2.67 & 3.07 & 1.29 & 2.02 & 2.67 & 5.55 \\
\hline $\mathrm{K}_{2} \mathrm{O}$ & 0.00 & 0.03 & 0.02 & 0.01 & 0.02 & 0.02 & 0.00 & 0.01 & 0.03 & 0.02 & 0.01 & 0.01 & 0.00 & 0.02 & 0.04 \\
\hline Total & 100.51 & 101.07 & 100.23 & 100.51 & 101.05 & 99.80 & 99.99 & 99.95 & 99.99 & 100.51 & 100.53 & 99.95 & 99.98 & 100.34 & 100.17 \\
\hline An & 82.6 & 68.5 & 73.2 & 72.6 & 75.1 & 61.5 & 85.6 & 75.2 & 86.9 & 75.9 & 72.3 & 88.3 & 81.6 & 76.0 & 51.1 \\
\hline
\end{tabular}

Table 3 (continued).

\begin{tabular}{lccccccr}
\hline Hole: & $894 \mathrm{G}$ & $894 \mathrm{G}$ & $894 \mathrm{G}$ & $894 \mathrm{G}$ & $894 \mathrm{G}$ & $894 \mathrm{G}$ & $894 \mathrm{G}$ \\
Core, section: & $19 \mathrm{R}-1$ & $19 \mathrm{R}-1$ & $19 \mathrm{R}-1$ & $19 \mathrm{R}-1$ & $19 \mathrm{R}-1$ & $19 \mathrm{R}-1$ & $19 \mathrm{R}-1$ \\
Interval $(\mathrm{cm}):$ & $77-79$ & $77-79$ & $77-79$ & $77-79$ & $77-79$ & $77-79$ & $77-79$ \\
Analysis no: & $\mathrm{D} 1 \mathrm{PC}$ & $\mathrm{D} 2 \mathrm{PC}$ & $5 \mathrm{G}$ & $6 \mathrm{G}$ & $\mathrm{E} 1 \mathrm{PC}$ & $\mathrm{E} 1 \mathrm{PR}$ & $\mathrm{E} 2 \mathrm{PC}$ \\
\hline & & & & & & & \\
\hline $\mathrm{SiO}_{2}$ & 46.74 & 48.54 & 48.72 & 49.14 & 47.73 & 52.52 & 46.84 \\
$\mathrm{Al}_{2} \mathrm{O}_{3}$ & 34.47 & 32.72 & 32.69 & 31.95 & 33.20 & 30.12 & 33.93 \\
$\mathrm{FeO}$ & 0.32 & 0.38 & 0.44 & 0.64 & 0.37 & 0.89 & 0.35 \\
$\mathrm{MgO}$ & 0.19 & 0.25 & 0.26 & 0.59 & 0.25 & 0.34 & 0.23 \\
$\mathrm{CaO}$ & 17.57 & 15.89 & 15.76 & 14.91 & 16.50 & 13.40 & 17.10 \\
$\mathrm{~N}_{2} \mathrm{O}$ & 1.52 & 2.53 & 2.52 & 2.63 & 2.11 & 3.70 & 1.74 \\
$\mathrm{~K}_{2} \mathrm{O}$ & 0.01 & 0.03 & 0.02 & 0.03 & 0.01 & 0.02 & 0.01 \\
$\mathrm{Total}$ & 100.82 & 100.32 & 100.42 & 99.89 & 100.16 & 100.98 & 100.20 \\
$\mathrm{An}$ & 86.5 & 77.5 & 77.4 & 75.7 & 81.2 & 66.6 & 84.4 \\
\hline
\end{tabular}

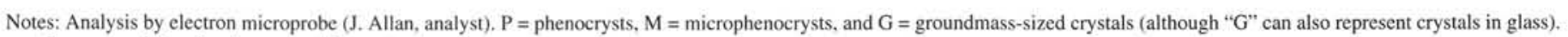
$\mathrm{C}=$ core and $\mathrm{R}=\mathrm{rim} . \mathrm{An}=$ anorthite content.

Table 4. Representative clinopyroxene analyses, Hole 894G.

\begin{tabular}{|c|c|c|c|c|c|c|}
\hline Hole: & $894 \mathrm{G}$ & $894 G$ & $894 G$ & $894 \mathrm{G}$ & $894 \mathrm{G}$ & $894 \mathrm{G}$ \\
\hline Core, section: & $2 \mathrm{R}-2$ & $2 \mathrm{R}-2$ & $2 \mathrm{R}-2$ & $2 \mathrm{R}-2$ & $2 \mathrm{R}-1$ & $2 \mathrm{R}-1$ \\
\hline Interval $(\mathrm{cm})$ : & $104-105$ & $104-105$ & $104-105$ & $104-105$ & $68-71$ & $68-71$ \\
\hline Analysis no.: & IGC & $2 \mathrm{GR}$ & $6 \mathrm{G}$ & $8 \mathrm{G}$ & $4 G$ & $5 G$ \\
\hline $\mathrm{SiO}_{2}$ & 50.81 & 49.54 & 49.91 & 48.65 & 50.25 & 49.65 \\
\hline $\mathrm{TiO}_{2}$ & 0.76 & 1.21 & 1.16 & 1.59 & 0.97 & 1.26 \\
\hline $\mathrm{Al}_{2} \mathrm{O}_{3}$ & 3.07 & 4.07 & 4.49 & 2.64 & 3.00 & 3.72 \\
\hline $\mathrm{Cr}_{2} \mathrm{O}_{3}$ & 0.14 & 0.43 & 0.27 & 0.02 & 0.03 & 0.16 \\
\hline $\mathrm{FeO}$ & 8.07 & 9.29 & 8.52 & 15.55 & 11.60 & 9.61 \\
\hline $\mathrm{MnO}$ & 0.20 & 0.20 & 0.20 & 0.40 & 0.31 & 0.25 \\
\hline $\mathrm{NiO}$ & 0.02 & $<0.01$ & $<0.01$ & 0.02 & 0.02 & 0.01 \\
\hline $\mathrm{MgO}$ & 15.70 & 15.11 & 14.66 & 12.92 & 15.67 & 14.80 \\
\hline $\mathrm{CaO}$ & 20.59 & 19.58 & 20.20 & 17.36 & 17.67 & 19.61 \\
\hline $\mathrm{Na}_{2} \mathrm{O}$ & 0.29 & 0.37 & 0.37 & 0.38 & 0.33 & 0.36 \\
\hline $\mathrm{K}_{2} \mathrm{O}$ & $<0.01$ & 0.01 & $<0.01$ & $<0.01$ & 0.01 & $<0.01$ \\
\hline Total & 99.67 & 99.80 & 99.78 & 99.53 & 99.86 & 99.43 \\
\hline $\mathrm{Mg} \#$ & 0.776 & 0.744 & 0.754 & 0.597 & 0.706 & 0.733 \\
\hline En & 0.448 & 0.439 & 0.432 & 0.379 & 0.449 & 0.432 \\
\hline Fs & 0.129 & 0.152 & 0.141 & 0.256 & 0.187 & 0.157 \\
\hline Wo & 0.423 & 0.409 & 0.428 & 0.366 & 0.364 & 0.411 \\
\hline
\end{tabular}

Notes: Analysis by electron microprobe (J. Allan, analyst). G = groundmass-sized crystals. $\mathrm{C}=$ core and $\mathrm{R}=$ rim. $\mathrm{Mg} \#=\mathrm{Mg} /\left(\mathrm{Mg}+\mathrm{Fe}^{2+}\right), \mathrm{En}=$ enstatite, $\mathrm{Fs}=$ ferrosilite and $\mathrm{Wo}_{\mathrm{O}}=$ wollastonite contents.

with cumulus olivine. Honey-brown euhedral $\mathrm{Cr}$-spinel is also abundant (about $1 \mathrm{vol} \%$ ), occurring as both inclusions in olivine and as loose crystals. Individual spinels may be quite large (up to $1 \mathrm{~mm}$ ), with crystals in contact with mesostasis surrounded by ferritchromite resorption rims (Pl. 1B). The mesostasis is dominated by microlitic, skeletal $\mathrm{An}_{69-75}$ plagioclase, commonly intergrown with anhedral to subhedral olivine and anhedral to plumose clinopyroxene. Rare, rounded, and obviously resorbed plagioclase grains occur up to 1.5
Table 5. Glass analysis of Sample 147-894D-1R-CC, $2-4 \mathrm{~cm}$.

\begin{tabular}{lccc}
\hline & Analyses & SD & $\begin{array}{c}\text { VG-2 } \\
\text { normalized }\end{array}$ \\
\hline $\mathrm{SiO}_{2}$ & 49.76 & 0.12 & 50.58 \\
$\mathrm{TiO}_{2}$ & 1.30 & 0.03 & 1.26 \\
$\mathrm{Al}_{2} \mathrm{O}_{3}$ & 15.33 & 0.07 & 15.48 \\
$\mathrm{FeO}$ & 9.96 & 0.16 & 9.66 \\
$\mathrm{MnO}$ & 0.15 & 0.03 & 0.14 \\
$\mathrm{MgO}$ & 8.48 & 0.08 & 8.14 \\
$\mathrm{CaO}$ & 12.02 & 0.10 & 12.38 \\
$\mathrm{Na} 2$ & 2.45 & 0.03 & 2.40 \\
$\mathrm{~K}_{2} \mathrm{O}$ & 0.03 & 0.01 & 0.03 \\
$\mathrm{P}_{2} \mathrm{O}_{5}$ & 0.06 & 0.02 & 0.07 \\
$\mathrm{Total}^{2}$ & 99.54 & & 100.14 \\
$\mathrm{Mg \#}$ & 0.628 & & 0.625 \\
& & & \\
\hline
\end{tabular}

Notes: $\mathrm{SD}=$ standard deviation of six analyses. VG-2 normalized analysis represents normalization to repeated (seven) analyses of Juan de Fuca glass standard VG-2 (Jarosowich et al., 1980). $\mathrm{Mg} /\left(\mathrm{Mg}+\mathrm{Fe}^{2+}\right)(\mathrm{Mg \#})$ calculated assuming $\mathrm{Fe}^{3+} / \mathrm{Fe}^{\text {Total }}$ of 0.10 , following Christie et al. (1986).

$\mathrm{mm}$ in size and are more anorthitic in composition (Analysis 4GC in Table 3), and represent evidence of mineral-melt disequilibria.

Olivine phenocrysts are $\mathrm{Fo}_{90}$ in composition, unzoned except at the outermost margins (to $\mathrm{Fo}_{83}$; Fig. 2). Groundmass olivine crystals are also less magnesian $\left(\mathrm{Fo}_{85-87}\right)$. Cr-spinel $\mathrm{Mg} /\left(\mathrm{Mg}+\mathrm{Fe}^{2+}\right)(\mathrm{Mg} \#)$ ranges from 0.74 to 0.79 , and $\mathrm{Cr} /\left(\mathrm{Cr}+\mathrm{Al}+\mathrm{Fe}^{3+}\right)$ ( $\left.\mathrm{Cr} \#\right)$ ranges from 0.26 to 0.36 . They are only slightly zoned (Fig. 2) and contain low amounts of ferric iron $\left(\mathrm{Fe}^{3+} /\left[\mathrm{Cr}+\mathrm{Al}+\mathrm{Fe}^{3+}\right]\right.$ or $\left.\mathrm{Fe \#} \leq 0.06\right)$ and $\mathrm{TiO}_{2}$ $(0.21 \%-0.31 \%)$. Cr-spinel inclusions in olivine have compositions similar to those of the larger crystals, but $\mathrm{Cr}$-spinel phenocryst rims and small groundmass crystals have slightly lower Mg\# (Table 2). Their compositions are similar to those reported from highly depleted, primitive N-MORB (e.g., Allan et al., 1988). 
Table 6. XRF analyses of basaltic samples, Holes 894F, 894G, 895A, and $895 \mathrm{C}$.

\begin{tabular}{lcccccc}
\hline Hole: & $894 \mathrm{~F}$ & $894 \mathrm{G}$ & $894 \mathrm{G}$ & $894 \mathrm{G}$ & $895 \mathrm{~A}$ & $895 \mathrm{C}$ \\
Core, section: & $3 \mathrm{R}-1$ & $2 \mathrm{R}-1$ & $2 \mathrm{R}-2$ & $19 \mathrm{R}-1$ & $2 \mathrm{R}-1$ & $4 \mathrm{R}-3$ \\
Interval $(\mathrm{cm}):$ & $123-128$ & $60-65$ & $95-100$ & $49-55$ & $91-95^{*}$ & $56-59$ \\
Unit: & 3 & 2 & 2 & 12 & & 8 \\
Rock: & Dike & Dike & Dike & Dike & Lava & Dike \\
\hline $\mathrm{SiO}_{2}$ & 48.02 & 48.23 & 47.62 & 46.34 & 49.86 & 44.24 \\
$\mathrm{TiO}_{2}$ & 1.00 & 0.94 & 0.87 & 0.88 & 1.61 & 1.25 \\
$\mathrm{Al}_{2} \mathrm{O}_{3}$ & 17.22 & 17.43 & 18.16 & 18.97 & 15.29 & 14.69 \\
$\mathrm{Fe}_{2} \mathrm{O}_{3}$ & 9.27 & 8.33 & 7.9 & 7.91 & 10.72 & 11.78 \\
$\mathrm{MnO}$ & 0.15 & 0.14 & 0.14 & 0.12 & 0.16 & 0.14 \\
$\mathrm{MgO}$ & 8.47 & 9.14 & 8.68 & 8.84 & 7.52 & 13.03 \\
$\mathrm{CaO}$ & 11.01 & 11.72 & 11.96 & 10.46 & 10.84 & 11.73 \\
$\mathrm{Na}{ }_{2} \mathrm{O}$ & 2.37 & 1.95 & 1.84 & 2.03 & 2.78 & 1.05 \\
$\mathrm{~K}_{2} \mathrm{O}$ & 0.02 & $\mathrm{ND}$ & $\mathrm{ND}$ & 0.04 & 0.18 & $\mathrm{ND}$ \\
$\mathrm{P}_{2} \mathrm{O}_{5}$ & 0.07 & 0.06 & 0.07 & 0.07 & 0.14 & 0.04 \\
$\mathrm{LOI}$ & 2.90 & 2.01 & 2.35 & 4.28 & & 2.81 \\
$\mathrm{~S}(\mathrm{wt} \%)$ & 0.176 & 0.134 & 0.129 & 0.17 & 0.08 & 0.038 \\
$\mathrm{Total}$ & 100.5 & 99.95 & 99.59 & 99.94 & 99.18 & 100.76 \\
$\mathrm{Mg} \#$ & 66.6 & 70.7 & 70.7 & 71.1 & 60.7 & 70.9 \\
$\mathrm{~V}$ & 222 & 231 & 231 & 251 & 296 & 229 \\
$\mathrm{Cr}$ & 396 & 392 & 295 & 594 & 289 & 492 \\
$\mathrm{Co}$ & 47 & 43 & 43 & 43 & & 60 \\
$\mathrm{Ni}$ & 211 & 218 & 206 & 378 & 115 & 540 \\
$\mathrm{Cu}$ & 94 & 90 & 89 & 85 & 68 & 18 \\
$\mathrm{Zn}$ & 75 & 59 & 60 & 66 & 84 & 43 \\
$\mathrm{Sr}$ & 91 & 92 & 92 & 100 & 128 & 130 \\
$\mathrm{Y}$ & 29 & 25 & 23 & 27 & 34 & 36 \\
$\mathrm{Zr}$ & 58 & 51 & 48 & 53 & 104 & 89 \\
$\mathrm{Nb}$ & 2 & 2 & 1 & 1 & & 3 \\
& & & & & &
\end{tabular}

Notes: Analysis by X-ray fluorescence of whole-rock powder (R. Pedersen, analyst), except for the sample marked with an asterisk, which is from Gillis, Mével, Allan, et al., 1993). Placement of samples in core denoted by site, section in core, and interval as measured from the top of the section. Inferred sample unit and origin is also given (dike or lava; Gillis, Mével, Allan, et al., 1993). LOI = loss on ignition and $\mathrm{ND}=$ not detected.

\section{Hole $894 E$}

Samples 147-894E-1R-CC, 10-13 cm, and 2R-1, 0-8 cm, represent small fragments of aphyric pillow basalts. Both contain $5 \%-$ $10 \%$ vesicles. Sample 147-894E-1R-CC, $10-13 \mathrm{~cm}$, is fresh and dominated by fine, skeletal, microlitic plagioclase (most $<200 \mu \mathrm{m}$ in length). Fine plumose clinopyroxene and occasional phenocrysts and groundmass grains of skeletal olivine (up to $600 \mu \mathrm{m}$ ) also occur. Sample 147-894E-2R-1, 0-8 cm, which is more coarsely crystalline, contains small amounts of carbonate and light green secondary clays in the vesicles. Plagioclase occurs as skeletal, elongate laths (to $>1$ $\mathrm{mm}$ ), often intergrown with skeletal olivine (up to $1 \mathrm{~mm}$ ). Between the larger crystals are sheafs and sprays of clinopyroxene, with a dusting of fine magnetite grains (several microns in size) between the skeletal clinopyroxene.

Sample 147-894E-3R-1, 34-38 cm, is a fine-grained, massive, moderately altered, microcrystalline basalt, interpreted by Gillis, Mével, Allan, et al. (1993) to represent a dike. Although containing sparse phenocrysts of euhedral plagioclase (up to $2 \mathrm{~mm}$ ), the rock is dominated by intergranular plagioclase and clinopyroxene, often exhibiting subophitic texture. Blocky Fe-Ti oxides make up 1\%-2\% of the groundmass. Both plagioclase and clinopyroxene are partially altered to clays, which make up $10 \%-15 \%$ of the rock.

\section{Hole $894 F$}

Sample $147-894 \mathrm{~F}-3 \mathrm{R}-1,125-128 \mathrm{~cm}$, is a massive, fine-grained, slightly to moderately altered aphyric basalt, containing about $1 \% \mathrm{eu}$ hedral, blocky to tabular plagioclase phenocrysts (up to $2 \mathrm{~mm}$ ) in a plagioclase microlite- and crystallite-dominated groundmass. Also present is euhedral olivine (up to $500 \mu \mathrm{m} ; 1 \%-2 \%$ of the rock), heavily altered in portions of the sample to secondary clays, as is the mesostasis. Clinopyroxene is present as cryptocrystalline sheafs. This sample exhibits a chilled intrusive contact with gabbroic rock, and so represents a dike (Gillis, Mével, Allan, et al., 1993).

\section{Hole $894 G$}

Two basaltic dikes were sampled in Hole 894G. They comprise $7.15 \%$ of the recovered section in this hole and occur in curated core from Section 147-894G-2R-1, $15 \mathrm{~cm}$ (28.8 mbsf), to $2 \mathrm{R}-2,127 \mathrm{~cm}$ (31.4 mbsf), and Sections 147-894G-19R-1, $48 \mathrm{~cm}$ (141.0 mbsf), to $19 \mathrm{R}-1,139 \mathrm{~cm}$ (142.2 mbsf). Both dikes are massive and moderately altered to low-temperature, secondary clays (from 15 to $20 \mathrm{vol} \%$ for the upper dike to $40 \mathrm{vol} \%$ or more for the lower dike). The Leg 147 scientific party interpreted that this hydrothermal alteration occurred during or immediately after the dikes intruded relatively cold gabbroic wallrock (Gillis, Mével, Allan, et al., 1993). Both dikes are olivine, $\mathrm{Cr}$-spinel, and plagioclase phyric, although the lower dike is considerably finer in average grain size and less phenocryst rich. Gillis, Mével, Allan, et al. (1993) give extensive petrographic descriptions of these dikes, summarized here with the mineral chemistry.

The upper dike (Unit 2 of the Hole 894G lithology; Gillis, Mével, Allan, et al., 1993) is coarsely porphyritic and holocrystalline, containing $6 \%-12 \%$ phenocrysts of subhedral plagioclase that contain scalloped and embayed crystal margins. The largest crystals $(>1 \mathrm{~cm})$ represent sutured-together phenocrysts, with their boundaries grown over with subsequent plagioclase. Transect P1 (Fig. 3) shows an EMP transect across such a grain; former grain boundaries can be recognized by sharp compositional zoning (Analyses P2 PC and P3 $\mathrm{PC}$ in Table 3, from Sample 147-894G-2R-1, 24-26 cm), presumably representing quench growth before accretion. Other individual phenocrysts contain compositional discontinuities that align with optical zoning (Fig. 3); they are typically $\mathrm{An}_{80-87}$ in composition. Phenocryst melt-inclusion abundance varies and does not correlate with composition. Groundmass plagioclase $\left(\mathrm{An}_{48-77}\right)$ is lathlike. Together with heavily altered, anhedral to subhedral clinopyroxene, it forms a finemedium grained groundmass with intergranular and poorly developed subophitic textures. The clinopyroxenes are low- $\mathrm{TiO}_{2}(0.8 \%-$ $1.6 \%$ ) augites similar to others reported from MORB tholeiites (e.g., Mazzullo and Bence, 1976; Perfit and Fornari, 1983; Allan et al., 1989). Table 4 illustrates that their compositional diversity is small, except for rare Fs-rich grains (Analysis 8G). As in other coarsegrained MORBs (e.g., Allan et al., 1989), $\mathrm{TiO}_{2}$ and $\mathrm{Al}_{2} \mathrm{O}_{3}$ do not show the usual close crystal-chemical coupling to $\mathrm{FeO} / \mathrm{MgO}$ (reflecting the $\mathrm{Ca}(\mathrm{Fe}, \mathrm{Ti})(\mathrm{Al}, \mathrm{Si})_{2} \mathrm{O}_{6}$ pyroxene component; Sack and Carmichael, 1984), indicating local increases in $\mathrm{FeO} / \mathrm{MgO}$ and $\mathrm{TiO}_{2}$ in magmatic liquids during extended cooling and crystallization. Skeletal magnetite (up to $100 \mu \mathrm{m}$ ) comprises about $1.5 \%$ of the groundmass and was not analyzed.

Olivine occurs as moderately to heavily altered, subhedral grains with embayed margins and makes up $1 \%-3 \%$ of the rock. The compositions of olivine cores average about $\mathrm{Fo}_{88}$; rims are rarely zoned to $\mathrm{Fo}_{75}$ (Table 2), although most crystals show little zoning. $\mathrm{Cr}$-spinel (up to $300 \mu \mathrm{m}$ ) is a minor but important accessory, making up $0.1 \%-$ $0.3 \%$ of the rock and occurring as loose groundmass grains, as inclusions within olivine, or attached to the sides of plagioclase. The $\mathrm{Cr}$ spinels in the groundmass show spectacular skeletal resorption rims (PI. 1C, ID), in which the spinel has been partially dissolved and changed in composition to ferritchromite. Figure 4 illustrates the lowering of $\mathrm{Cr}$-spinel $\mathrm{Mg} \#$ and the rise in $\mathrm{Fe \#}$ as the ferritchromite rims are approached. Sporadically, magnetite occurs on the margins of the corroded rims (Analysis 5GR from Sample 147-894G-2R-2, 104-105 cm, in Table 1). Considering the Cr-spinel cores, Mg\# varies from 0.71 to 0.78 , Cr\# from 0.18 to 0.41 , with low Fe\# (0.04$0.06)$ and $\mathrm{TiO}_{2}(0.22 \%-0.45 \%)$. These $\mathrm{Cr}$-spinels are similar to others from primitive, depleted N-MORB, with their low $\mathrm{TiO}_{2}$ exemplifying the depleted nature of the host magma (Dick and Bullen, 1984; Allan et al., 1988, 1989). 
Table 7. INA analyses of basaltic samples, Holes 894D, 894E, 894G, 895A, and 895D.

\begin{tabular}{|c|c|c|c|c|c|c|c|c|c|c|c|c|c|c|c|}
\hline Hole: & 894D & $894 \mathrm{D}$ & 894D & $894 \mathrm{E}$ & $894 \mathrm{E}$ & $894 \mathrm{E}$ & $894 \mathrm{G}$ & $894 \mathrm{G}$ & $894 \mathrm{G}$ & $895 \mathrm{~A}$ & $895 \mathrm{D}$ & & & & \\
\hline Core, section: & IR-I & IR-CC & IR-CC & IR-CC & $2 \mathrm{R}-1$ & $3 R-1$ & $2 \mathrm{R}-1$ & $2 \mathrm{R}-2$ & 19R-I & $2 \mathrm{R}-1$ & IR-1 & & & & \\
\hline Interval (cm): & $106-110$ & 4-6 & $2-4$ & $0-1$ & $0-8$ & $34-38$ & $60-65$ & $95-100$ & $49-55$ & $91-95$ & $11-16$ & & & & \\
\hline Unit: & & 1 & 2 & & 1 & 4 & 2 & 2 & 12 & & & BHVO & & BHVO & \\
\hline Rock: & Lava & Lava & Lava & Lava & Lava & Lava & Dike & Dike & Dike & Lava & Lava & analyzed & SD & accepted & $\mathrm{SD}$ \\
\hline $\mathrm{Na}$ & $1.85 \%$ & $1.78 \%$ & $1.24 \%$ & $1.84 \%$ & $1.89 \%$ & $1.66 \%$ & $1.61 \%$ & $1.47 \%$ & $1.73 \%$ & $2.04 \%$ & $2.05 \%$ & $1.59 \%$ & $0.08 \%$ & $1.64 \%$ & $0.06 \%$ \\
\hline $\mathrm{Fe}$ & $7.45 \%$ & $7.51 \%$ & $6.72 \%$ & $7.40 \%$ & $6.87 \%$ & $6.36 \%$ & $5.99 \%$ & $5.87 \%$ & $5.71 \%$ & $7.48 \%$ & $8.76 \%$ & $8.59 \%$ & $0.10 \%$ & $8.51 \%$ & $0.19 \%$ \\
\hline $\mathrm{Sc}$ & 40.3 & 26.4 & 40.5 & 39.9 & 40.3 & 36.0 & 31.0 & 29.9 & 29.8 & 40.3 & 43.8 & 31.1 & 0.4 & 30 & 2 \\
\hline $\mathrm{Cr}$ & 357 & 944 & 334 & 367 & 420 & 376 & 425 & 320 & 721 & 294 & 105 & 295 & 5 & 290 & 30 \\
\hline Co & 44.3 & 67.5 & 45.7 & 45.8 & 45.5 & 43.4 & 43.2 & 42.6 & 50.1 & 44.2 & 45.6 & 45.1 & 0.4 & 45 & \\
\hline $\mathrm{Ni}$ & 102 & 705 & 108 & 148 & 118 & 151 & 208 & 194 & 318 & 95 & 57 & 124 & 14 & 120 & 16 \\
\hline $\mathrm{Zn}$ & 93 & 75 & 85 & 88 & 78 & 73 & 63 & 59 & 57 & 94 & 136 & 114 & 5 & 177 & 26 \\
\hline $\mathrm{La}$ & 1.35 & 0.91 & 1.42 & 2.72 & 2.19 & 1.26 & 1.26 & 1.14 & 1.19 & 3.55 & 6.31 & 15.2 & 0.4 & 16.70 & 0.80 \\
\hline $\mathrm{Ce}$ & 5.14 & 4.66 & 5.35 & 9.49 & 7.49 & 4.93 & 4.85 & 4.57 & 6.07 & 11.80 & 19.70 & 38.0 & 0.7 & 40 & 4 \\
\hline $\mathrm{Sm}$ & 2.72 & 1.71 & 2.69 & 3.65 & 2.62 & 2.40 & 2.24 & 2.01 & 2.03 & 3.56 & 6.36 & 6.07 & 0.15 & 6.2 & 0.7 \\
\hline Eu & 1.08 & 0.67 & 1.11 & 1.41 & 1.02 & 0.95 & 0.82 & 0.78 & 0.87 & 1.31 & 2. & 2.09 & 0. & 2.1 & 0.4 \\
\hline $\mathrm{Tb}$ & 0.70 & 0.41 & 0.85 & 1.08 & 0.74 & 0.61 & 0.65 & 0.53 & 0.58 & 0.88 & 1.56 & 0.92 & 0.09 & 1.0 & 0.3 \\
\hline $\mathrm{Yb}$ & 2.83 & 1.66 & 2. & 3.52 & 2. & 2.26 & 2.12 & 1. & I. & 3.17 & 6.17 & 1.82 & 0.06 & 2.1 & 0.5 \\
\hline $\mathrm{Lu}$ & 0.43 & 0.25 & 0.43 & 0.53 & 0.39 & 0.39 & 0.31 & 0.29 & 0.33 & 0.49 & 0.99 & 0.28 & 0.03 & 0.32 & \\
\hline $\mathrm{Hf}$ & 1.95 & 1.11 & 2.02 & 2.29 & 1.94 & 1.65 & 1.43 & 1.43 & 1.31 & 2.81 & 5.19 & 4.61 & 0.08 & 4.1 & 0.3 \\
\hline $\mathrm{Ta}$ & 0.05 & 0.04 & 0.03 & 0.08 & 0.07 & 0.05 & 0.03 & $<.03$ & 0.03 & 0.19 & 0.31 & 1.19 & 0.03 & 1.08 & 0.18 \\
\hline$(\mathrm{La} / \mathrm{Sm}) \mathrm{N}$ & 0.30 & 0.32 & 0.32 & 0.45 & 0.51 & 0.32 & 0.34 & 0.35 & 0.36 & 0.61 & 0.60 & 1.52 & & 1.64 & \\
\hline$(\mathrm{Ta} / \mathrm{Hf}) \mathrm{W}$ & 0.20 & 0.28 & 0.12 & 0.27 & 0.28 & 0.24 & 0.16 & 0.16 & 0.18 & 0.53 & 0.46 & 2.01 & & 2.05 & \\
\hline
\end{tabular}

Notes: Analyses are by instrumental neutron activation (INA) analysis (J. Allan and S. Lakkapragada, analysts). Placement of samples in core denoted by site, section in core, and interval as measured from top of section. Inferred sample unit and origin is also given (dike or lava; see Gillis, Mével, Allan, et al., 1994). SD = standard deviation. Accepted values for BHVO, based on six samples (from Gladney et al., 1983). ( $\mathrm{La} / \mathrm{Sm})_{\mathrm{N}}$ and $(\mathrm{Ta} / \mathrm{Hf})_{\mathrm{N}}$ are chondrite normalized (Masuda et al., 1973; Anders and Ebihara, 1982).

Table 8. ICP-MS analyses of basaltic samples, Holes $894 \mathrm{~F}, 894 \mathrm{G}$, and $895 \mathrm{C}$.

\begin{tabular}{|c|c|c|c|c|c|c|c|c|c|}
\hline Hole: & $894 \mathrm{~F}$ & $894 \mathrm{G}$ & $894 \mathrm{G}$ & $894 \mathrm{G}$ & $895 \mathrm{C}$ & & & & \\
\hline Core, section: & $3 R-1$ & $2 R-1$ & $2 \mathrm{R}-1$ & $19 \mathrm{R}-1$ & $4 \mathrm{R}-3$ & & & & \\
\hline Interval $(\mathrm{cm})$ & $123-128$ & $60-65$ & $95-100$ & $49-55$ & $56-59$ & & & & \\
\hline Unit: & 3 & 2 & 2 & 12 & 8 & BHVO & BHVO & BHVO & \\
\hline Rock: & Dike & Dike & Dike & Dike & Dike & $(N=2)$ & SD & accepted & $\mathrm{SD}$ \\
\hline $\mathrm{La}$ & 1.45 & 1.44 & 1.16 & 1.23 & 2.58 & 18.3 & 1.0 & 16.7 & 0.8 \\
\hline $\mathrm{Ce}$ & 4.68 & 4.31 & 3.82 & 4.02 & 7.56 & 38.0 & 2.2 & 40 & 4 \\
\hline Pr & 0.92 & 0.91 & 0.77 & 0.78 & 1.31 & 5.29 & 0.34 & 5.6 & \\
\hline $\mathrm{Nd}$ & 5.08 & 4.75 & 4.19 & 4.36 & 6.76 & 22.9 & 0.7 & 25 & 3 \\
\hline $\mathrm{Sm}$ & 2.24 & 2.06 & 1.72 & 180 & 2.23 & 5.58 & 0.01 & 6.2 & 0.7 \\
\hline $\mathrm{Eu}$ & 0.94 & 0.90 & 0.72 & 0.88 & 1.00 & 1.99 & 0.02 & 2.1 & 0.4 \\
\hline $\mathrm{Gd}$ & 2.96 & 2.98 & 2.71 & 2.77 & 3.54 & 6.24 & 0.25 & 5.35 & 0.46 \\
\hline $\mathrm{Tb}$ & 0.516 & 0.562 & 0.496 & 0.503 & 0.631 & 0.866 & 0.015 & 1.0 & 0.3 \\
\hline Dy & 3.58 & 3.75 & 3.29 & 3.34 & 4.36 & 5.15 & 0.08 & 4.8 & \\
\hline Ho & 0.783 & 0.782 & 0.737 & 0.695 & 0.958 & 0.874 & 0.067 & $\begin{array}{l}4.0 \\
0.93\end{array}$ & \\
\hline $\mathrm{Er}$ & 2.27 & 2.43 & 1.97 & 2.04 & 2.81 & 2.29 & 0.12 & 2.1 & \\
\hline $\mathrm{Tm}$ & 0.363 & 0.361 & 0.288 & 0.304 & 0.432 & 0.302 & 0.002 & 0.30 & 0.04 \\
\hline $\mathrm{Yb}$ & 2.08 & 2.13 & 1.77 & 1.91 & 2.77 & 1.73 & 0.10 & 2.1 & 0.5 \\
\hline & 0.277 & 0.344 & 0.291 & 0.311 & 0.435 & 0.257 & 0.005 & 0.32 & \\
\hline$(\mathrm{La} / \mathrm{Sm}) \mathrm{N}$ & 0.39 & 0.43 & 0.41 & 0.42 & 0.71 & 2.00 & & 1.64 & \\
\hline
\end{tabular}

Notes: Analyses are by inductively coupled mass-spectrometry (ICP-MS) (T. Falloon, analyst). Placement of samples in core denoted by site, section in core, and interval as measured from the top of the section. The inferred sample unit and origin are also given (dike or lava; see Gillis, Mével. Allan, et al., 1994). SD = standard deviation. Accepted values for BHVO from Gladney et al. (1983). ( $\mathrm{La} / \mathrm{Sm})_{\mathrm{N}}$ represents the chondritic normalization of $\mathrm{La} / \mathrm{Sm}$ (Masuda et al., 1973).

The lower dike (Unit 12 of the Hole 894G lithology) exhibits a chilled, fine-grained contact with gabbronorite wallrock. The groundmass changes from glassy (originally) and spherulitic to microlitic away from the contact, with the fine-grained mesostasis changing from pervasive to moderate alteration to secondary clays away from the contact. Euhedral to subhedral plagioclase phenocrysts comprise $2 \%-3 \%$ of the rock, range up to $6 \mathrm{~mm}$ in size, and contain abundant melt inclusions. They are highly anorthitic (to $\mathrm{An}_{87}$; Table 3), with some crystals showing sharp internal compositional zoning associated with optical zoning (Fig. 3). In contrast, groundmass plagioclase laths and microlites are more sodic, as are phenocryst rims $\left(\mathrm{An}_{65-77} ;\right.$ Table 3$)$.

Euhedral olivine (up to $3 \mathrm{~mm}$ ) is completely altered and comprises $3 \%-5 \%$ of the rock. In contrast, cores of light reddish brown euhedral $\mathrm{Cr}$-spinel (up to $0.3 \mathrm{~mm}$ ) are often relatively fresh, bounded by spongy alteration and resorption rims of ferritchromite that are thinner close to the dike margin. The $\mathrm{Cr}$-spinels occur both as loose crystals and as inclusions in olivine; their fresh cores have high Mg\#
(0.72-0.77), low Fe\# $(0.04-0.05)$ and $\mathrm{TiO}_{2}(0.26 \%-0.38 \%)$, and somewhat variable $\mathrm{Cr} \#(0.25 \%-0.40 \%)$. As with the Unit 2 dike $\mathrm{Cr}$ spinels, their mineral chemistry is similar to others reported from low-Ti, primitive and depleted N-MORB (Allan et al., 1988). Clinopyroxene occurs as elongate, skeletal crystallites in sheaflike clusters in the coarsest groundmass and was not analyzed.

\section{Site 895}

Sample $147-895 \mathrm{~A}-2 \mathrm{R}-1,91-95 \mathrm{~cm}$, is a highly altered, aphyric basalt, with $<1 \%$ phenocrysts of euhedral plagioclase (up to $0.8 \mathrm{~mm}$ ) and trace amounts of pervasively altered olivine (up to $0.3 \mathrm{~mm}$ ) and Cr-spinel (up to $0.2 \mathrm{~mm}$ ) in a fine-grained, highly altered microlitic to spherulitic groundmass (Gillis, Mével, Allan, et al., 1993). This sample likely represents a pillow lava fragment.

Sample $147-895 \mathrm{C}-4 \mathrm{R}-3,56-59 \mathrm{~cm}$, is a highly altered, massive, medium-grained basalt, originally containing plagioclase and olivine phenocrysts, that has been metamorphosed to the amphibolite grade 


\section{Cr-Spinel}
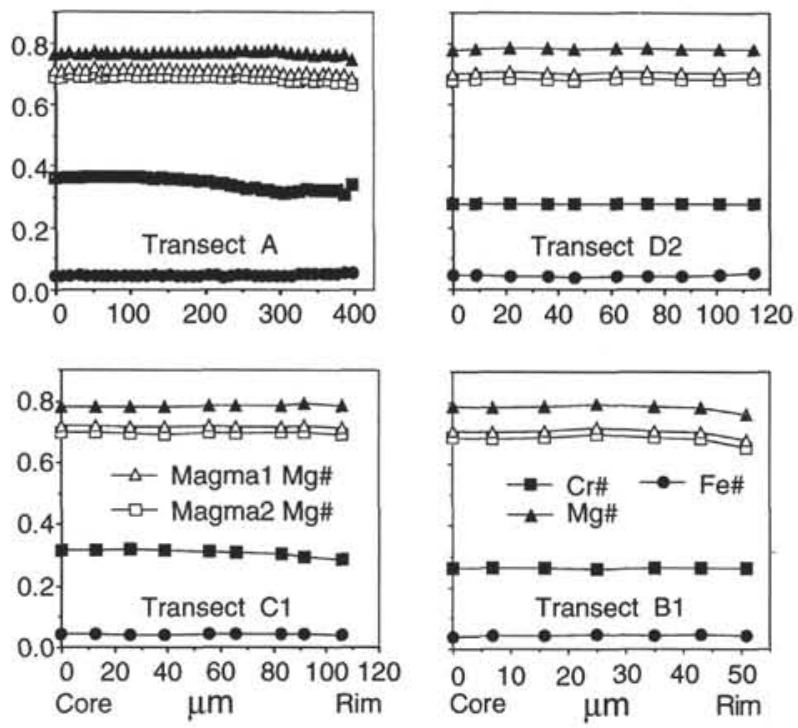

Olivine
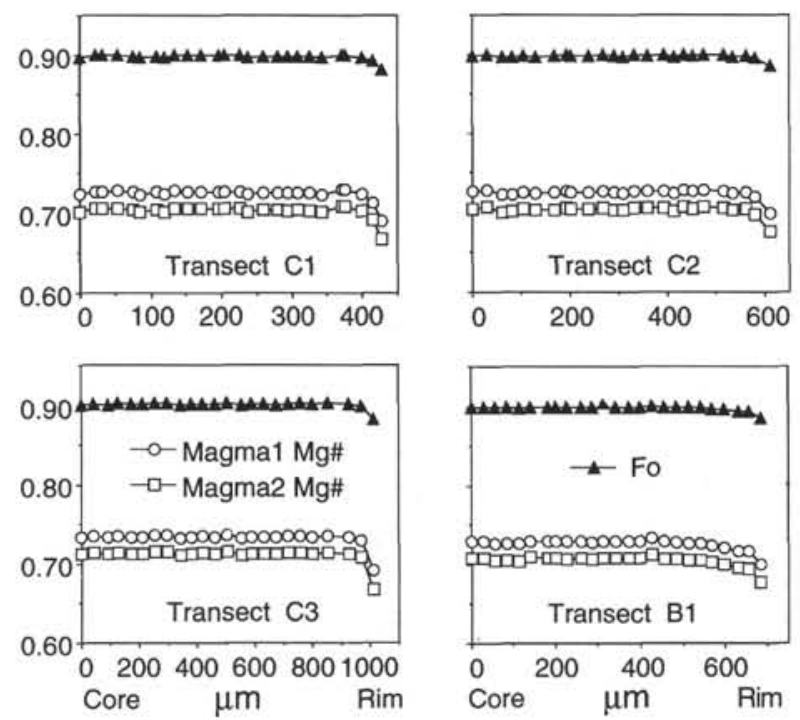

Figure 2. Core-to-rim electron microprobe transects across $\mathrm{Cr}$-spinel and olivine from Sample 147-894D-1R-CC, 4-6 cm. Mg\# = Mg/(Mg+Fe $\left.{ }^{2+}\right), \mathrm{Cr} \#=$ $\mathrm{Cr} /\left(\mathrm{Cr}+\mathrm{Al}+\mathrm{Fe}^{3+}\right)$, $\mathrm{Fe} \#=\mathrm{Fe}^{3+} /\left(\mathrm{Cr}+\mathrm{Al}+\mathrm{Fe}^{3+}\right)$, and $\mathrm{Fo}=$ olivine forsterite content. Magma $\mathrm{Mg} \#$ refers to equilibrium silicate liquid $\mathrm{Mg} /\left(\mathrm{Mg}+\mathrm{Fe}^{2+}\right)$ calculated either from olivine (Roeder and Emslie, 1970) or Cr-spinel (Allan, 1992) compositions, with Magmal and Magma2 assuming that the $\mathrm{Mg}-\mathrm{Fe}^{2+}$ melt-olivine $\mathrm{Kd}$ is 0.3 and 0.27 , respectively. Note that both phases are zoned to slightly less Mg-rich compositions at their margins, and that their calculated equilibrium silicate liquid Mg\#s closely match.

(Gillis, Mével, Allan, et al., 1993). Although contacts are missing, it likely represents a dike, probably metamorphosed during cooling after intrusion.

Sample 147-895D-1R-1, 11-16 cm, is a fresh, slightly plagioclase-clinopyroxene-phyric basalt, containing a few percent of small vesicles. Plagioclase phenocrysts comprise $1 \%-2 \%$ of the rock and are elongate laths to blocky in shape. They are commonly intergrown in glomeroporphyritic clumps with skeletal to anhedral clinopyrox-
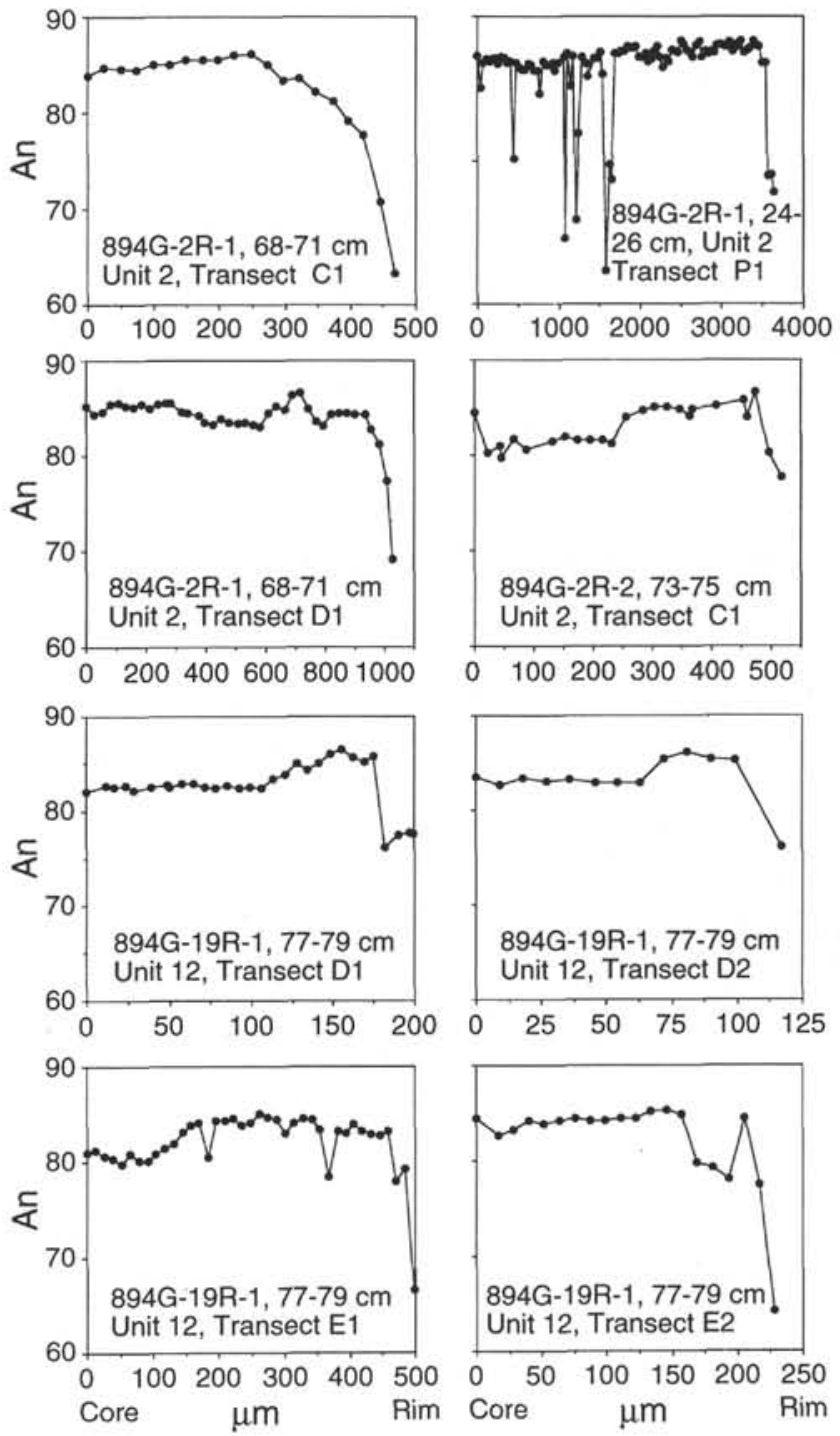

Figure 3. Core-to-rim electron microprobe transects across plagioclase phenocrysts from the two dikes sampled at Hole 894G. An $=$ anorthite content. Note that the sharp reverse zoning visible in some crystals is not associated with agglomerated grain boundaries.

ene, which may reach $0.8 \mathrm{~mm}$ in size. Anhedral olivine occurs sporadically in the sheaf-spherule-dominated groundmass and is always less than $100 \mu \mathrm{m}$ in size. This sample likely came from near the rim of a lava pillow.

\section{GEOCHEMISTRY}

Major element glass data and whole-rock XRF, INA, and ICP-MS data are presented in Tables 5-8, with chondrite-normalized (Masuda et al., 1973) REE plots and N-MORB-normalized (Sun and McDonough, 1989) incompatible element "spider" plots presented in Figures 5 and 6 . The small sample size $\left(<2-3 \mathrm{~cm}^{3}\right)$ of some Leg 147 basaltic samples has precluded obtaining a complete set of major element XRF data. As most of these samples are aphyric and very fine grained, it is felt that the analyzed trace element chemistry is representative of the erupted magma chemistry. This is not true for several of the samples affected by crystal accumulation or alteration. In par- 

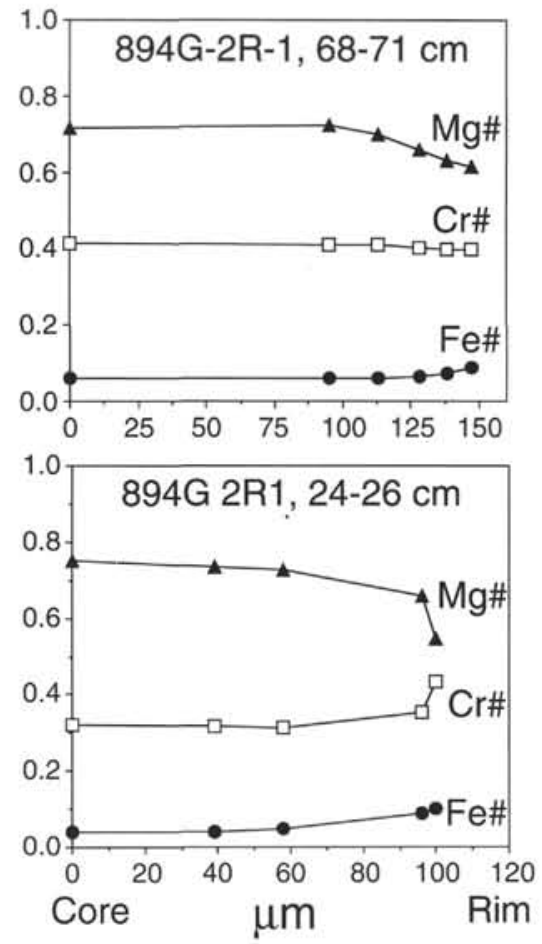

Figure 4. Core-to-rim electron microprobe transects across partially resorbed $\mathrm{Cr}$-spinel from Hole 894G Unit 2 dike samples. $\mathrm{Mg} \#=\mathrm{Mg} /\left(\mathrm{Mg}+\mathrm{Fe}^{2+}\right), \mathrm{Cr} \#=$ $\mathrm{Cr} /\left(\mathrm{Cr}+\mathrm{Al}+\mathrm{Fe}^{3+}\right)$, and $\mathrm{Fe} \#=\mathrm{Fe}^{3+} /\left(\mathrm{Cr}+\mathrm{Al}+\mathrm{Fe}^{3+}\right)$. Note the increase in $\mathrm{Fe} \#$ and decrease in $\mathrm{Mg} \#$ toward the ferritchromite/magnetite $\mathrm{Cr}$-spinel margins.

ticular, the picritic Sample 147-894D-1R-CC, 4-6 cm, has accumulated perhaps $25 \%$ olivine, leading to unrealistically high $\mathrm{Cr}, \mathrm{Co}$, and $\mathrm{Ni}$ values, as well as a general dilution of the abundance of the incompatible elements. Nevertheless, the shape of patterns in Figures 5 and 6 should be little affected, as the elements in these plots do not significantly partition into olivine and spinel (e.g., Irving, 1978). In addition, the chemistry of the highly metamorphosed Sample 147. $895 \mathrm{C}-4 \mathrm{R}-3,56-59 \mathrm{~cm}$, has been strongly modified by alteration, as evidenced by its metamorphic mineralogy, its enriched $\mathrm{MgO}$ and depleted $\mathrm{SiO}_{2}$ relative to typical MORB, and its very low $\mathrm{K}_{2} \mathrm{O}$ and $\mathrm{P}_{2} \mathrm{O}_{5}$. Interestingly, the shape of its REE plot seems little affected, in comparison with other samples from Site 895 (Fig. 5).

Overall, the basaltic samples from both Sites 894 and 895 represent LREE-depleted and other incompatible element-depleted, tholeiitic N-MORB (Basaltic Volcanism Study Group, 1981), with flat medium to heavy REE patterns (Fig. 5). Site 894 samples are significantly more depleted in LREE and other highly incompatible elements than both Site 895 samples and typical N-MORB (Figs. 5, 6). The high-field-strength elements (HFSE) Ta and $\mathrm{Nb}$ are particularly depleted, so much so that these samples are reminiscent of the geochemical signatures, without the large-ion-lithophile element (LILE) enrichment, of highly depleted backarc basin basalt such as from the Lau Basin (Hawkins and Melchior, 1985; Hawkins and Allan, 1994). It is necessary to note here that the Ta values are considered more reliable indicators of the magnitude of highly incompatible HFSE depletion, as the relative INA counting uncertainties for Ta (roughly $20 \%$ at the $0.03 \mathrm{ppm}$ level) are much better than the relative XRF analytical uncertainty for $\mathrm{Nb}$ at the $1-2 \mathrm{ppm}$ level (about $50 \%$ ). Within the Site 894 sample set, the dike samples and the lava Sample 147-894D-1R-CC, 4-6 cm, are quite primitive, with their major and trace element compositions approaching what might be considered primary MORB liquids (Basaltic Volcanism Study Group, 1981; Kinzler and Grove, 1992). The other Site 894 samples are more evolved, with Sample 147-894D-1R-CC, 2-4 cm, having an Mg\# of about 0.63 (Table 5). Samples 147-894D-1R-CC, 2-4 cm, and 1R-1, $106-110 \mathrm{~cm}$, could be fragments of the same lava flow, as they share nearly identical trace-element chemistry and mineralogy.

Samples from Site 895 contain substantially higher amounts of Ta and LREE than samples from Site 894 (Tables 6, 7); they are also similar in their incompatible element concentration patterns to typical N-MORB (Fig. 6). As an illustration, $(\mathrm{Ta} / \mathrm{Hf})_{\mathrm{N}}$ is $0.12-0.28$ and $(\mathrm{La} / \mathrm{Sm})_{\mathrm{N}}$ is $0.30-0.51$ in the Site 894 samples, yet they are $0.46-0.53$ and $0.60-0.71$, respectively, in the Site 895 samples. Sample 147$895 \mathrm{D}-1 \mathrm{R}-1,11-16 \mathrm{~cm}$, has the highest incompatible content and lowest compatible content of any of the Leg 147 basaltic samples. This is consistent with petrographic observations that show an abundance of clinopyroxene, greatly subordinate amounts of olivine, and the absence of Cr-spinel, all of which indicate that this sample is highly evolved, with comparable $\mathrm{N}-\mathrm{MORB}$ having Mg\#s well below 0.60 (e.g., Allan et al., 1987, 1989).

\section{DISCUSSION}

\section{Inferences from Mineralogy and Mineral Chemistry}

The composition of olivine and $\mathrm{Cr}$-spinel in these samples provides important constraints on the petrogenesis of their host lavas, and also provides direct estimates of the host melt $\mathrm{Mg}$ \# which crystallized these phases (Roeder and Emslie, 1970; Allan et al., 1988; Allan, 1992, 1994). The estimate of melt Mg\# from Cr-spinel composition uses the algorithm derived by Allan (1992, 1994), which assumes that $\mathrm{Cr}$-spinel behaves as an ideal reciprocal solution model (Sack, 1982; Allan et al., 1988) and that there is ideal mixing between $\mathrm{Mg}$ and $\mathrm{Fe}^{2+}$ in the host silicate liquid. The model follows the experimental results of Roeder and Reynolds (1991) with regard to the pressure effect on spinel-liquid equilibrium as being negligible over the pressures of interest ( $<10 \mathrm{kbar}$ ), and requires the assumption of a $\mathrm{K}_{\mathrm{D}}$ for olivine-liquid $\mathrm{Mg}-\mathrm{Fe}^{2+}$ exchange. Quench glass-olivine relations in Sample 147-894D-1R-CC, 4-6 cm, give a range for this $K_{D}$ of $0.27-0.29$, assuming $\mathrm{Fe}^{3+} / \mathrm{Fe}^{\text {total }}=0.1$. This is within the range of $0.26-0.3$ typically found in tholeiitic basalts with analyzed quench glass (Bender et al., 1978; Perfit and Fornari, 1983; Allan et al., 1987, 1989; Hawkins and Allan, 1994). Values for this $K_{D}$ of 0.27 and 0.3 are adopted here, which correspond to a calculated free energy of exchange $\left(\Delta \mathrm{G}_{\mathrm{EX}}\right)$ for $\mathrm{Mg}-\mathrm{Fe}^{2+}$ between $\mathrm{Cr}$-spinel and melt of 3.14 and $2.83 \mathrm{kcal} / \mathrm{gfw}$, respectively; in practical terms, the higher $\mathrm{K}_{\mathrm{D}}$ value results in melt $\mathrm{Mg} \#$ estimates that are about 0.02 higher.

Figure 2 and Tables 1 and 2 give estimates for the $\mathrm{Mg \#}$ of the melt that produced the olivine and $\mathrm{Cr}$-spinel of the picritic basalt Sample 147-894D-1R-CC, 2-4 cm. The interiors of these minerals predict melt $\mathrm{Mg} \#$ to have been $0.69-0.73$, with olivine yielding slightly higher estimates. The relatively unzoned nature of the phenocryst interiors gives confidence that they were in equilibrium with the predicted melt composition. The relatively fayalitic rims of the olivine phenocrysts, the more fayalitic composition of the groundmass olivines, the resorbed margins of the Cr-spinel, and the scalloped margins of the large, apparently xenocrystal An-rich plagioclase all imply disequilibrium between the phenocrysts/xenocrysts and host melt, implying that a magma-mixing event occurred shortly before eruption between the predicted primitive melt and another that was more evolved.

Phase chemistry also imposes important constraints regarding petrogenesis of the Hole 894G dikes. The Cr-spinel and olivine core compositions from the dike Units 2 and 12 predict equilibrium melt $\mathrm{Mg \# s}$ of about $0.66-0.70$. The XRF whole-rock Mg\#s, assuming a likely $\mathrm{Fe}^{3+} / \mathrm{Fe}^{\text {Total }}$ of 0.1 (Christie et al., 1986), are about 0.71 , implying that some slight $\mathrm{Mg}$ enrichment occurred during hydrothermal alteration, with substitution of $\mathrm{Mg}$ for $\mathrm{Ca}$ during the breakdown of clinopyroxene into secondary phyllosilicates (Seyfried, 1987; Allan, 1992). This proposal is supported by the relatively lower dike $\mathrm{CaO} /$ $\mathrm{Na}_{2} \mathrm{O}$ whole-rock ratios as compared to glass compositions from $\mathrm{La}-$ 
A
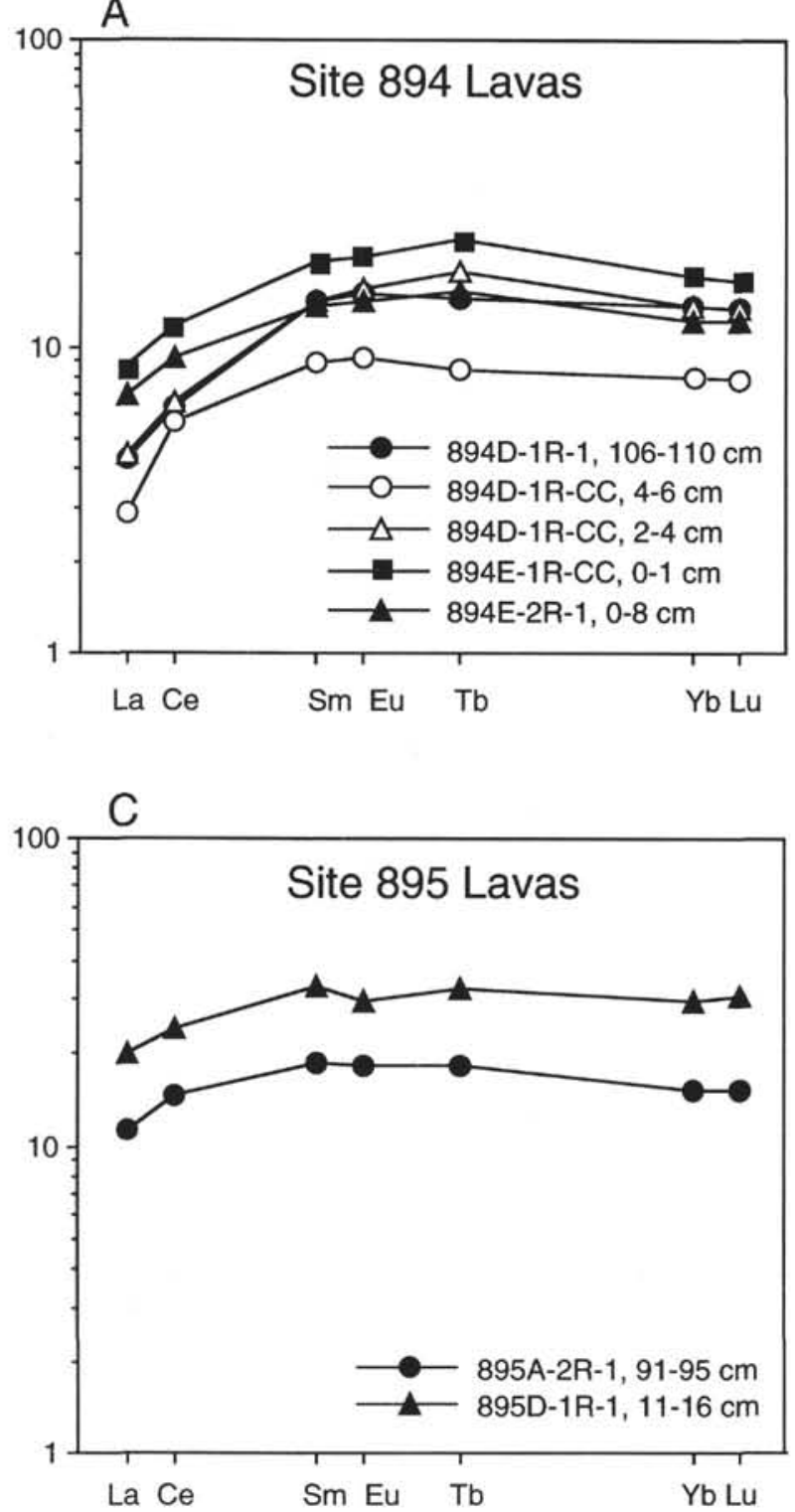

B
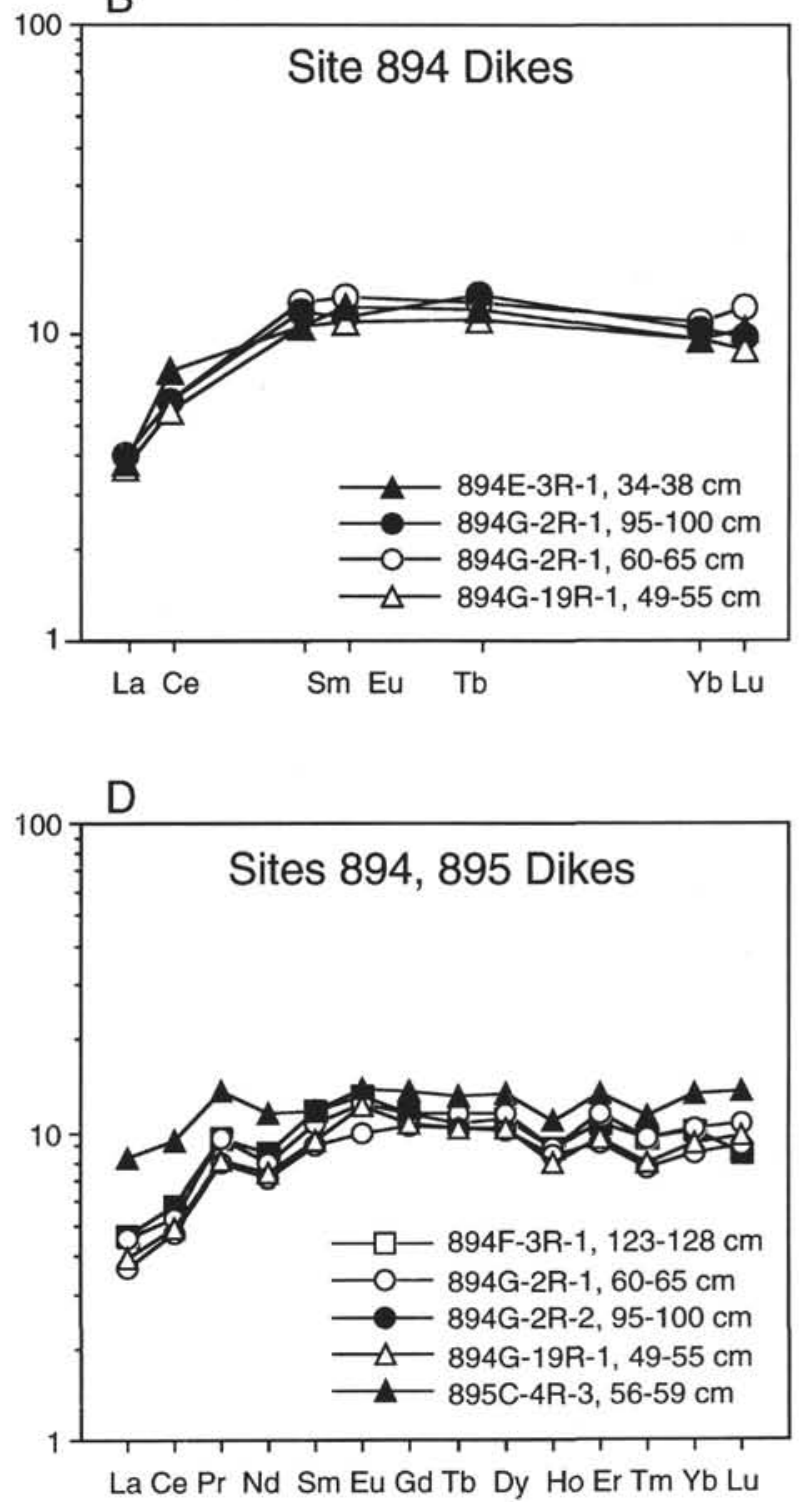

Figure 5. Chondrite meteorite-normalized (Masuda et al., 1973; Leedy values/1.2246) rare earth element composition of Leg 147 basaltic rocks using INA data (A-C; J. Allan and S. Lakkapragada, analysts) and ICP-MS data (D; T. Falloon, analyst). Note the LREE-depleted nature of all samples, and that the Site 894 samples are substantially more depleted in these elements than are the Site 895 samples.

mont Seamount lavas and whole-rock compositions from Hole 504B, even though these sets of samples share large plagioclase phenocrysts whose compositions approach $\mathrm{An}_{90}$ (Kempton et al., 1985; Allan et al., 1989).

Plagioclase phenocrysts in both dike units illustrate a complex origin, as they show sharp normal and reverse internal zoning (Fig. 3). In particular, most crystals show a gradual to sharp increase in An content as the rim is approached, implying that at least one magma mixing or assimilation event had occurred during the petrogenetic history of both dike units. Unfortunately, alteration has prevented the preservation of such features in the outer portions of olivine and $\mathrm{Cr}$ spinel, but it is important to note that the range in $\mathrm{Cr}$-spinel $\mathrm{Al}_{2} \mathrm{O}_{3}$ and $\mathrm{Cr}_{2} \mathrm{O}_{3}$ composition in both dike units (Table 1 ) is unusually broad, especially so given that the $\mathrm{Cr}$-spinel cores appear to be in equilibrium with a magma of similar $\mathrm{Mg \#}$. This variation in $\mathrm{Cr}$-spinel composition could also reflect magma mixing. Despite the primitive chemis- try of the dike units, they appear to be derivative magmas and therefore are not primary.

\section{Comparison with Nearby MORB}

Figure 7 shows comparative "spider" plots for basaltic samples from Sites 894 and 895 with a variety of other east-central Pacific basalts. The more primitive Site 894 basalts are geochemically quite similar to primitive depleted basalts from Hole 504B, south of the Cocos-Nazca spreading center. The Hole $894 \mathrm{G}$ dike rocks and the primitive Hole 504B basalts share a mineralogy characterized by abundant, large plagioclase phenocrysts, subordinate olivine phenocrysts, and abundant Cr-spinel (Natland et al., 1983; Kempton et al., 1985). The Hole $894 \mathrm{G}$ dikes are nearly identical in composition and mineralogy to highly depleted N-MORB lavas from off-axis, nearEPR seamounts, like the Lamont Seamounts (Allan et al., 1989) and 

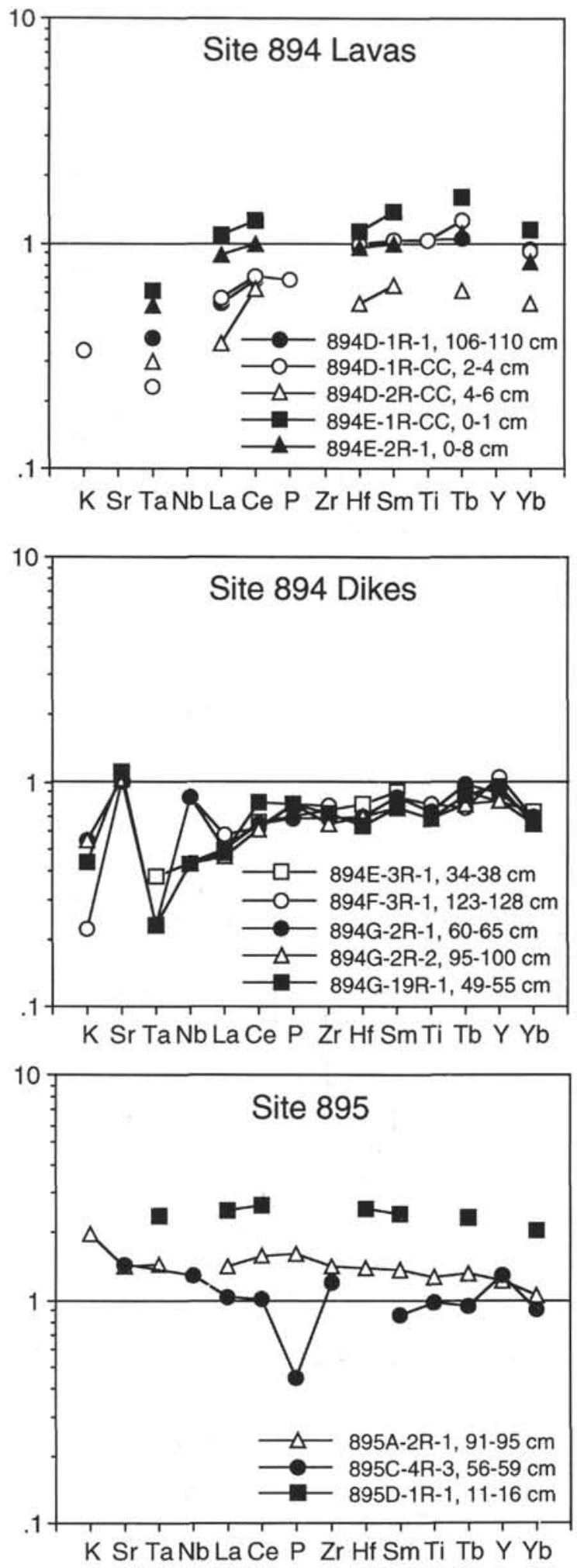

Figure 6. N-MORB-normalized (Sun and McDonough, 1989) analyses of basaltic samples from Leg 147. Element compositions are not connected by lines if a gap occurs in the data. The REE plotted represent INA data, except for Samples 147-894F-3R-1, 123-128 cm, and 147-895C-4R-3, 56-59 cm, which use ICP-MS data. Note that Site 894 samples are substantially depleted in $\mathrm{Ta}$ and $\mathrm{Nb}$ compared to Site 895 samples and to typical $\mathrm{N}$ MORB. others occurring on the Cocos Plate (Batiza and Vanko, 1984; Batiza et al., 1990; Allan et al., 1994); these are quite unlike the more LREEenriched, less primitive, and less phyric samples from the EPR and incipient Cocos-Nazca spreading center to the north (Fig. 7; Langmuir et al., 1986; Allan et al., 1989; Batiza and Niu, 1992; Lonsdale et al., 1992; Allan, 1995). Highly plagioclase-phyric basalts have also been collected on Nautile dives to the adjacent Cocos-Nazca ridge system (Constantin et al., 1993).

The closest compositional and mineralogical analogues to the picritic basalt Sample 147-894D-1R-CC, 4-6 cm, are picritic basalts from the Sequiros Fracture Zone, also representing off-axis volcanism near the EPR (Natland, 1980, 1989). Altered, picritic, talus basalt of similar mineralogy was collected by the Nautile submarine on the south flank of the Hess Deep intrarift ridge, as have primitive, depleted basalts with olivine and plagioclase phenocrysts (Hekinian et al., 1993). Similar fresh, glassy primitive N-MORB was dredged in May 1990 by the Atlantis II (Nilsson, 1993) from the Hess Deep intrarift ridge, at a point approximately halfway between Sites 894 and 895 (Dredge D4; Fig. 1). This basalt was erupted directly on top of gabbro and peridotite; an analysis of this sample is given in Table 9 and plotted in Figure 7. This basalt, bearing crystals of plagioclase (3\%-5\%; up to $1.5 \mathrm{~mm}$ ), olivine ( $3 \%-5 \%$; up to $2 \mathrm{~mm}$ ), and trace amounts of Cr-spinel (up to $120 \mu \mathrm{m}$ ), is more enriched in LILE and HFSE than are Site 894 dikes and basalts, and somewhat more primitive than Site 894 basalts. The moderately evolved Site 894 samples are similar in mineralogy to basalts sampled from the northern slope of the Hess Deep (samples that were presumably erupted at the adjacent EPR at 0.5-1.0 Ma; Nilsson and Natland, 1991; J. Natland, unpubl. data, 1994). However, they are generally more depleted in LREE, as the Hess Deep north slope samples have $(\mathrm{La} / \mathrm{Sm})_{\mathrm{N}}$ of $0.55-0.59$.

In contrast to the Site 894 basalts, samples from Site 895 are relatively similar in composition and mineralogy to basalts from the EPR, the incipient Cocos-Nazca spreading center to the north of Hess Deep, and the Hess Deep north wall. Site 895 basalts share similar $(\mathrm{La} / \mathrm{Sm})_{\mathrm{N}}$ and $(\mathrm{Ta} / \mathrm{Hf})_{\mathrm{N}}$ ratios with EPR basalts to the north (Allan et al., 1989; Allan, 1995), and similar $(\mathrm{La} / \mathrm{Sm})_{\mathrm{N}}$ to the Hole $894 \mathrm{G}$ gabbroic section.Despite being somewhat more evolved, they also share similar geochemical characteristics with the D4 intrarift ridge dredge sample.

\section{Origin of the Leg 147 Samples: Off-ridge or Ridge-crest Magmatism?}

The fundamental characteristic of Site 894 samples is their strong relative depletions in LREE and in the HFSE Ta and $\mathrm{Nb}$, as shown in the "N-MORB" normalized "spider" plots (Figs. 5-7), with the magnitude of these relative depletions impossible to generate by crystal fractionation or moderate variations in source melting (Pearce et al., 1981). These depletions are marked compared to $\mathrm{Sr}$ in "spider" plots, and raise the possibility that the relative incompatibility assigned to $\mathrm{Sr}$ in these plots by Sun and McDonough (1989) may be too high. This depleted signature signifies that the Site 894 basaltic samples, like the depleted basalts from Hole 504B and the near-ridge Lamont Seamounts, must have been derived from a highly depleted mantle source, a source significantly more depleted than the one which has produced nearby EPR lavas. Of significance here is that the Hole 894G gabbroic samples, which should represent residual, mid-level crust generated at the adjacent EPR, have a higher average $(\mathrm{La} / \mathrm{Sm})_{\mathrm{N}}$ of $0.52 \pm 0.08$ (Pedersen et al., this volume) vs. a lower average ( $\mathrm{La} /$ $\mathrm{Sm})_{\mathrm{N}}$ of $0.41 \pm 0.02$ (ICP-MS data; same lab as Pedersen et al. data) and $0.36 \pm 0.07$ (INA data) for the Site 894 samples. Allan et al. (1989) modeled mantle source melting for production of the similar highly depleted Lamont seamount lavas and concluded that they could have been derived from a mantle source that had undergone previous melt extraction at the adjacent ridge. The Site 894 basaltic 

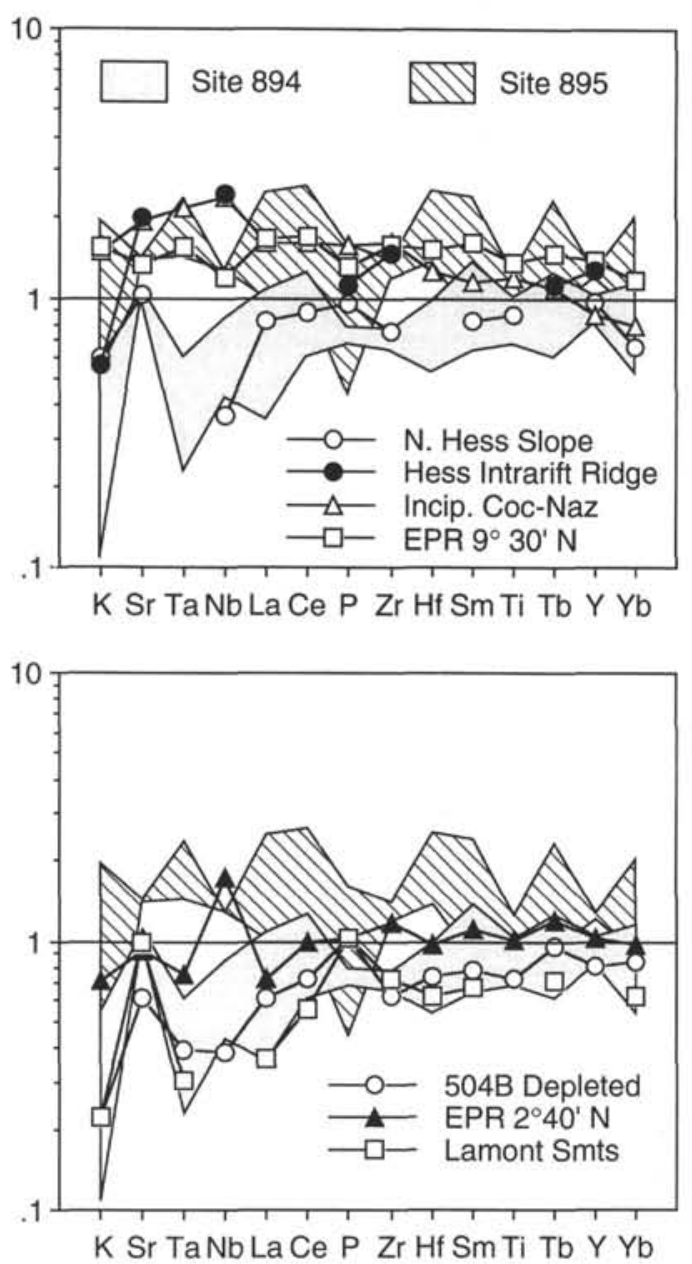

Figure 7. Data fields for basaltic samples from Sites 894 and 895 as compared with other regional basaltic samples. The sawtooth shape of the Site 895 maximum concentrations is a result of the lack of elemental data for Sample 147-895D-1R-1, 11-16 cm; on the other hand, the apparent dips in minimum Site $895 \mathrm{P}$ and $\mathrm{K}$ result from the loss by metamorphic alteration of Sample 147-895C-4R-3, 56-59 cm. Hess Slope data represents an average of primitive lava samples exposed by faulting at the north rim of the Hess Deep, representing lavas originally erupted at the adjacent EPR (J. Natland, unpubl. data, 1994). Hess Intrarift Ridge represents fresh, glassy basalt collected from Dredge D4 (Fig. 1), representing recent Hess Deep volcanism. Incip. Coc-Naz represents an average of samples collected from the incipient Cocos-Nazca spreading center, north of Hess Deep (Fig. 1) and propagating eastward; EPR $2^{\circ} 40^{\prime}$ represents an average of samples collected from the EPR northwest of the Hess Deep (data for both from Lonsdale et al., 1992). EPR $9^{\circ} 30^{\prime} \mathrm{N}=$ average composition of basaltic glass collected at Site 864 on the EPR at $9^{\circ} 30^{\prime} \mathrm{N}$ (Storms, Batiza, et al., 1993; Allan, 1994, 1995), typical of EPR N-MORB composition. 504B Depleted $=$ average composition of depleted "D" basaltic samples from Hole 504B (Kempton et al., 1985), using Ta data from Emmermann (1985). Lamont Smts = composition of samples from a flanking cone of the near-EPR Lamont Seamounts (Dredge F2 of Allan et al., 1989).

samples, particularly the most depleted samples, may have had a similar origin.

Another fundamental observation regarding the Site 894 dikes is that they did not experience the pervasive alteration to lower amphibolite of gabbro section from Holes 894F and 894G, which instead underwent much lower temperature hydrothermal alteration that probably occurred immediately after intrusion into cool wallrock
Table 9. Electron microprobe and X-ray fluorescent analyses of basalt glass from Dredge D4 (Hess intrarift ridge).

\begin{tabular}{lcl}
\hline & Dredge D4 & $\mathrm{SD}$ \\
\hline Microprobe $(N=8 ;$ & wt $\%):$ & \\
$\mathrm{SiO}_{2}$ & 49.59 & 0.18 \\
$\mathrm{TiO}_{2}$ & 1.44 & 0.02 \\
$\mathrm{Al}_{2} \mathrm{O}_{3}$ & 16.47 & 0.32 \\
$\mathrm{FeO}$ & 8.81 & 0.22 \\
$\mathrm{MnO}$ & 0.17 & 0.02 \\
$\mathrm{MgO}$ & 8.02 & 0.15 \\
$\mathrm{CaO}$ & 12.07 & 0.03 \\
$\mathrm{Na}{ }_{2} \mathrm{O}$ & 2.81 & 0.14 \\
$\mathrm{~K}_{2} \mathrm{O}$ & 0.05 & 0.00 \\
$\mathrm{P}_{2} \mathrm{O}_{5}$ & 0.10 & 0.01 \\
$\mathrm{Total}$ & 99.53 & \\
$\mathrm{Mg} \#$ & 0.643 & \\
& & \\
$\mathrm{XRF}(N=2 ; \mathrm{ppm}):$ & & \\
$\mathrm{V}$ & 266 & 3 \\
$\mathrm{Ni}$ & 173 & 3 \\
$\mathrm{Sr}$ & 181 & 0 \\
$\mathrm{Y}$ & 36 & 0 \\
$\mathrm{Zr}$ & 105 & 2 \\
$\mathrm{Nb}$ & 5.5 & 0.5 \\
$\mathrm{Ba}$ & 8 & 1 \\
& & \\
\hline
\end{tabular}

Notes: J. Natland and K. Nilsson, analysts. For location of Dredge D4, see Figure I (see also Nilsson, 1993). $\mathrm{SD}=$ standard deviation. $\mathrm{Mg} /\left(\mathrm{Mg}+\mathrm{Fe}^{2+}\right)(\mathrm{Mg} \#)$ calculated assuming $\mathrm{Fe}^{3+} / \mathrm{Fe}^{\text {Total }}$ of 0.10 , following Christie et al. (1986).

(Gillis, Mével, Allan, et al., 1993). In addition, contact relations also show that the country rock was relatively cool during intrusion, as evidenced by the Unit 12 dike/wallrock chilled contact from Hole $894 \mathrm{G}$, and by recrystallization of gabbro secondary sulfides to marcasite in the vicinity of the dikes (Gillis, Mével, Allan, et al., 1993). This evidence shows that dike intrusion occurred substantially after the Site 894 gabbros had been emplaced at the EPR. Together with the geochemical evidence, the most probable explanation for the depleted Site 894 basaltic dike and lava samples is that they represent small amounts of off-axis magmatism associated with the opening of the Hess Deep, with source melting caused by decompression associated with the rifting. The presence of fresh, glassy Dredge D4 pillow lavas on the Hess Deep intrarift flank clearly shows that off-ridge volcanism is active on the intrarift ridge. The specific timing of the eruption of the Site 894 basaltic lava fragments may be mixed; the occurrence of some in turbidites on top of a tilted fault block suggests that they may have been transported before the intrarift ridge was uplifted (Gillis, Mével, Allan, et al., 1993). Finally, interaction of rising melt with depleted mantle harzburgite may reinforce the profound depletion in the HFSE seen in the Site 894 samples (after Kelemen et al., 1993; Allan and Dick, this volume), a process that should be more efficient in the off-axis environment where the melt/wallrock ratio is lower.

Site 895 basaltic samples display geochemical characteristics similar to basalts erupted both at the EPR and on the intrarift ridge (Dredge D4 samples; Fig. 7). High-temperature amphibolite metamorphism that the dike sample (Sample 147-895C-4R-3, 56-59 cm) underwent is consistent with intrusion into hot country rock, probably at or near the EPR ridge crest. The lava sample (Sample 147$895 \mathrm{~A}-2 \mathrm{R}-1,91-95 \mathrm{~cm}$ ) is highly altered as well, consistent with long exposure on the seafloor after eruption. In contrast, Sample 147$895 \mathrm{D}-1 \mathrm{R}-1,11-16 \mathrm{~cm}$, is relatively fresh, implying recent eruption and signifying (with the Dredge D4 sample) that the degree of depletion in the sub-Hess Deep mantle is heterogenous, as is also shown to the north by off-axis seamount volcanism on the Cocos Plate (Allan et al., 1994).

\section{CONCLUSIONS}

Leg 147 obtained a number of basaltic rock samples at Sites 894 and 895 from the Hess Deep intrarift ridge, representing dikes cutting 
both gabbroic and peridotite sections, and transported fragments of surficial, pillowed lava flows.

Site 894 basaltic dike samples are highly primitive, with melt $\mathrm{Mg} \# \mathrm{~s}$, predicted from mineral-melt equilibria, of up to 0.70 . One lava sample represents a highly primitive, picritic basalt, crystallized from a melt with a $\mathrm{Mg} \#$ as high as 0.73 . Together with other, more evolved lava samples, Site 894 basalts are extremely depleted in LREE, Ta, and $\mathrm{Nb}$, with $(\mathrm{La} / \mathrm{Sm})_{\mathrm{N}}$ and $(\mathrm{Ta} / \mathrm{Hf})_{\mathrm{N}}$ ratios varying from 0.30 to 0.51 and from 0.12 to 0.28 , respectively. The intrusive relations, mineralogy, and geochemistry of these samples support an off-axis origin of these samples, with derivation during the opening of the Hess Deep from an extremely depleted mantle source.

Site 895 samples represent evolved basalts less depleted in LREE, $\mathrm{Ta}$, and $\mathrm{Nb}$ than Site 894 samples, with $(\mathrm{La} / \mathrm{Sm})_{\mathrm{N}}$ and $(\mathrm{Ta} / \mathrm{Hf})_{\mathrm{N}}$ ratios varying from 0.60 to 0.71 and from 0.46 to 0.53 , respectively. These characteristics denote derivation from a less depleted mantle, similar in composition to that underlying the adjacent EPR. Intrusive relations and geochemical characteristics support a mixed origin for these samples, with some originating at or near the EPR ridge crest, and others representing volcanism associated with Hess Deep opening.

The marked depletion in $\mathrm{Ta}, \mathrm{Nb}$, and La relative to $\mathrm{Sr}$ in "spider" plots indicates that the positioning by Sun and McDonough (1989) of Sr to a position more "incompatible" than these elements is incorrect for highly depleted N-MORB. Instead, $\mathrm{Sr}$ appears to be only moderately incompatible in these rocks.

\section{ACKNOWLEDGMENTS}

We thank the SEDCO/BP 471 crew, the ODP engineers, and the ODP technical staff for their herculean efforts to recover these samples. We also thank P. Castillo, R. Kinzler, and P. Meyer for positive, helpful reviews. J. Allan is grateful to NSF and USSAC for supporting these studies, and to his eagle-eyed editorial colleagues at ODP for sharpening the manuscript.

\section{REFERENCES}

Allan, J.F., 1992. Cr-spinel as a petrogenetic indicator: deducing magma composition from spinels in highly altered basalts from the Japan Sea, Sites 794 and 797. In Tamaki, K., Suyehiro, K., Allan, J., McWilliams, M., et al., Proc. ODP, Sci. Results, $127 / 128$ (Pt. 2): College Station, TX (Ocean Drilling Program), 837-847.

1994. Cr-spinel in depleted basalts from the Lau backarc basin: petrogenetic history from Mg-Fe crystal-liquid exchange. In Hawkins, J., Parson, L., Allan, J., et al., Proc. ODP, Sci. Results, 135: College Station, TX (Ocean Drilling Program), 565-583.

, 1995. Trace element geochemistry of Leg 142 basalts by instrumental neutron activation analysis. In Batiza, R., Storms, M.A., and Allan, J. (Eds.), Proc. ODP, Sci. Results, 142: College Station, TX (Ocean Drilling Program), 87-89.

Allan, J.F., Batiza, R., and Lonsdale, P.F., 1987. Petrology and chemistry of lavas from seamounts flanking the East Pacific Rise axis, $21^{\circ} \mathrm{N}$ : implications concerning the mantle source composition for both seamount and adjacent EPR lavas. In Keating, B.H., Fryer, P., Batiza, R., and Boehlert, G.W. (Eds.), Seamounts, Islands, and Atolls. Geophys. Monogr., Am. Geophys. Union, 43:255-282.

Allan, J.F., Batiza, R., Perfit, M.R., Fornari, D.J., and Sack, R.O., 1989. Petrology of lavas from the Lamont Seamount Chain and adjacent East Pacific Rise, $10^{\circ}$ N. J. Petrol., 30:1245-1298.

Allan, J.F., Batiza, R., and Sack, R.O., 1994. Geochemical characteristics of Cocos Plate seamount lavas. Contrib. Mineral. Petrol., 116:47-61.

Allan, J.F., Sack, R.O., and Batiza, R., 1988. Cr-rich spinels as petrogenetic indicators: MORB-type lavas from the Lamont Seamount Chain, eastern Pacific. Am. Mineral., 73:741-753.

Anders, E., and Ebihara, M., 1982. Solar-system abundances of the elements. Geochim. Cosmochim. Acta, 46:2363-2380.
Basaltic Volcanism Study Project (BSVP), 1981. Basaltic Volcanism on the Terrestrial Planets: New York (Pergamon Press).

Batiza, R., and Niu, Y., 1992. Petrology and magma chamber processes at the East Pacific Rise-9 ${ }^{\circ} 30$ N. J. Geophys. Res., 97:6779-6797.

Batiza, R., Niu, Y., and Zayac, W.C., 1990. Chemistry of seamounts near the East Pacific Rise: implications for the geometry of sub-axial mantle flow. Geology, 18:1122-1125.

Batiza, R., and Vanko, D., 1984. Petrology of young Pacific seamounts. $J$. Geophys. Res., 89:11235-11260.

Bender, J.F., Hodges, F.N., and Bence, A.E., 1978. Petrogenesis of basalts from the Project FAMOUS area: experimental study from 0 to 15 kbars. Earth Planet. Sci. Lett., 41:277-302.

Bryan, W.B., 1974. Fe-Mg relationships in sector-zoned submarine basalt plagioclase. Earth Planet. Sci. Lett., 24:157-165.

Byerly, G.R., Melson, W.G., Nelen, J.A., and Jarosewich, E., 1976. Abyssal basaltic glasses as indicators of magma compositions. In Mason, B. (Ed.), Mineral Science Investigations, 1974-1975. Smithson. Contrib. Earth Sci., 19:22-30.

Carmichael, I.S.E., 1967. The iron-titanium oxides of salic volcanic rocks and their associated ferromagnesian silicates. Contrib. Mineral. Petrol., 14:36-64.

Christie, D.M., Carmichael, I.S.E., and Langmuir, C.H., 1986. Oxidation states of mid-ocean ridge basalt glasses. Earth Planet. Sci. Lett., 79:397411.

Constantin, M., Hekinian, R., Ackermand, D., Stoffers, P., and Francheteau, J., 1993. Upper mantle and lower crust exposed in the Easter microplate (south Pacific). Terra Nova, 5:184-185.

Dick, H.J.B., and Bullen, T., 1984. Chromian spinel as a petrogenetic indicator in abyssal and alpine-type peridotites and spatially associated lavas. Contrib. Mineral. Petrol., 86:54-76.

Emmermann, R., 1985. Basement geochemistry, Hole 504B. In Anderson, R.N., Honnorez, J., Becker, K., et al., Init. Repts. DSDP, 83: Washington (U.S. Govt. Printing Office), 183-199.

Francheteau, J., Armijo, R., Cheminée, J.L., Hekinian, R., Lonsdale, P.F., and Blum, N., 1990. 1 Ma East Pacific Rise oceanic crust and uppermost mantle exposed by rifting in Hess Deep (equatorial Pacific Ocean). Earth Planet. Sci. Lett., 101:281-295.

Gillis, K., Mével, C., Allan, J., et al., 1993. Proc. ODP, Init. Repts., 147: College Station, TX (Ocean Drilling Program).

Gladney, E.S., Burns, C.E., and Roelandts, I., 1983. 1982 compilation of elemental concentrations in eleven United States Geological Survey rock standards. Geostand. Newsl., 7:3-227.

Hawkins, J.W., and Allan, J.F., 1994. Petrologic evolution of Lau Basin Sites 834 through 839. In Hawkins, J., Parson, L., Allan, J., et al., Proc. ODP, Sci. Results, 135: College Station, TX (Ocean Drilling Program), 427470.

Hawkins, J.W., and Melchior, J.T., 1985. Petrology of Mariana Trough and Lau Basin basalts. J. Geophys. Res., 90:11431-11468.

Hekinian, R., Bideau, D., Francheteau, J., Cheminee, J.L., Armijo, R., Lonsdale, P., and Blum, N., 1993. Petrology of the East Pacific Rise crust and upper mantle exposed in the Hess Deep (eastern equatorial Pacific). $J$. Geophys. Res., 98:8069-8094.

Irving, A.J., 1978. A review of experimental studies of crystal/liquid trace element partitioning. Geochim. Cosmochim. Acta, 42:743-770.

Jarosewich, E., Nelen, J.A., and Norberg, J.A., 1980. Reference samples for electron microprobe analysis. Geostand. Newsl., 4:43-47.

Kelemen, P.B., Shimizu, N., and Dunn, T., 1993. Relative depletion of niobium in some arc magmas and the continental crust: partitioning of $\mathrm{K}$, $\mathrm{Nb}, \mathrm{La}$, and $\mathrm{Ce}$ during melt/rock reaction in the upper mantle. Earth Planet. Sci. Lett., 120:111-133.

Kempton, P.D., Autio, L.K., Rhodes, J.M., Holdaway, M.J., Dungan, M.A., and Johnson, P., 1985. Petrology of basalts from Hole 504B, Deep Sea Drilling Project, Leg 83. In Anderson, R.N., Honnorez, J., Becker, K., et al., Init. Repts. DSDP, 83: Washington (U.S. Govt. Printing Office), 129-164.

Kinzler, R.J., and Grove, T.L., 1992. Primary magmas of mid-ocean ridge basalts, 2: applications. J. Geophys. Res., 97:6907-6926.

Langmuir, C.H., Bender, J.F., and Batiza, R., 1986. Petrological and tectonic segmentation of the East Pacific Rise, $5^{\circ} 30 \mathrm{~N}-14^{\circ} 30^{\prime} \mathrm{N}$. Nature, 322:422-429.

Lonsdale, P., 1988. Structural pattern of the Galapagos microplate and evolution of the Galapagos triple junction. J. Geophys. Res., 93:13551-13574. 
Lonsdale, P., Blum, N., and Puchelt, H., 1992. The RRR triple junction at the southern end of the Pacific-Cocos East Pacific Rise. Earth Planet. Sci. Lett., 109:73-95.

Masuda, A., Nakamura, N., and Tanaka, T., 1973. Fine structures of mutually normalized rare-earth patterns of chondrites. Geochim. Cosmochim. Acta, 37:239-248.

Mazzullo, L.J., and Bence, A.E., 1976. Abyssal tholeiites from DSDP Leg 34: the Nazca Plate. J. Geophys. Res., 81:4327-4351.

Natland, J.H., 1980. Crystal morphologies in basalts dredged and drilled from the East Pacific Rise near $9^{\circ} \mathrm{N}$ and the Siqueiros fracture zone. In Rosendahl, B.R., Hekinian, R., et al., Init. Repts. DSDP, 54: Washington (U.S. Govt. Printing Office), 605-634.

, 1989. Partial melting of a lithologically heterogeneous mantle: inferences from crystallization histories of magnesian abyssal tholeiites from the Siqueiros Fracture Zone. In Saunders, A.D., and Norry, M.J. (Eds.), Magmatism in the Ocean Basins. Geol. Soc. Spec. Publ. London, $42: 41-70$

Natland, J.H., Adamson, A.C., Laverne, C., Melson, W.G., and O'Hearn, T., 1983. A compositionally nearly steady-state magma chamber at the Costa Rica Rift: evidence from basalt glass and mineral data, Deep Sea Drilling Project Sites 501, 504, and 505. In Cann, J.R., Langseth, M.G., Honnorez, J., Von Herzen, R.P., White, S.M., et al., Init. Repts. DSDP, 69: Washington (U.S. Govt. Printing Office), 811-858.

Nilsson, K., 1993. Oxidation state, sulfur speciation, and sulfur concentration in basaltic magmas: examples from Hess Deep and the Lau Basin [Ph.D. dissert.]. Univ. of California-San Diego.

Nilsson, K., and Natland, J.H., 1991. Oxide crystallization and $\mathrm{fO}_{2}$ during differentiation of abyssal tholeiites and gabbros at Hess Deep, E. Pacific. Eos, 72:526.

Pearce, J.A., Alabaster, T., Shelton, A.W., and Searle, M.P., 1981. The Oman ophiolite as a Cretaceous arc-basin complex: evidence and implications. Philos. Trans. R. Soc. London A, 300:299-317.
Perfit, M.R., and Fornari, D.J., 1983. Geochemical studies of abyssal lavas recovered by DSRV Alvin from eastern Galapagos Rift, Inca Transform, and Ecuador Rift, 2: phase chemistry and crystallization history. J. Geophys. Res., 88:10530-10550.

Roeder, P.L., and Emslie, R.F., 1970. Olivine-liquid equilibrium. Contrib. Mineral. Petrol., 29:275-289.

Roeder, P.L., and Reynolds, I., 1991. Crystallization of chromite and chromium solubility in basaltic liquid. J. Petrol., 32:909-934.

Sack, R.O., 1982. Spinels as petrogenetic indicators: activity-composition relations at low pressures. Contrib. Mineral. Petrol., 79:169-186.

Sack, R.O., and Carmichael, I.S.E., 1984. $\mathrm{Fe}^{2+}-\mathrm{Mg}^{2+}$ and $\mathrm{TiAl}_{2}-\mathrm{MgSi}_{2}$ exchange reactions between clinopyroxene and silicate melts. Contrib. Mineral. Petrol., 85:103-115.

Seyfried, W.E., Jr., 1987. Experimental and theoretical constraints on hydrothermal alteration processes at mid-ocean ridges. Annu. Rev. Earth Planet. Sci., 15:317-335.

Storms, M.A., Batiza, R., et al., 1993. Proc. ODP. Init. Repts., 142: College Station, TX (Ocean Drilling Program).

Sun, S.-S., and McDonough, W.F., 1989. Chemical and isotopic systematics of oceanic basalts: implications for mantle composition and processes. In Saunders, A.D., and Norry, M.J. (Eds.), Magmatism in the Ocean Basins. Geol. Soc. Spec. Publ. London, 42:313-345.

Date of initial receipt: 1 August 1994

Date of acceptance: 5 January 1995

Ms 147SR-010 

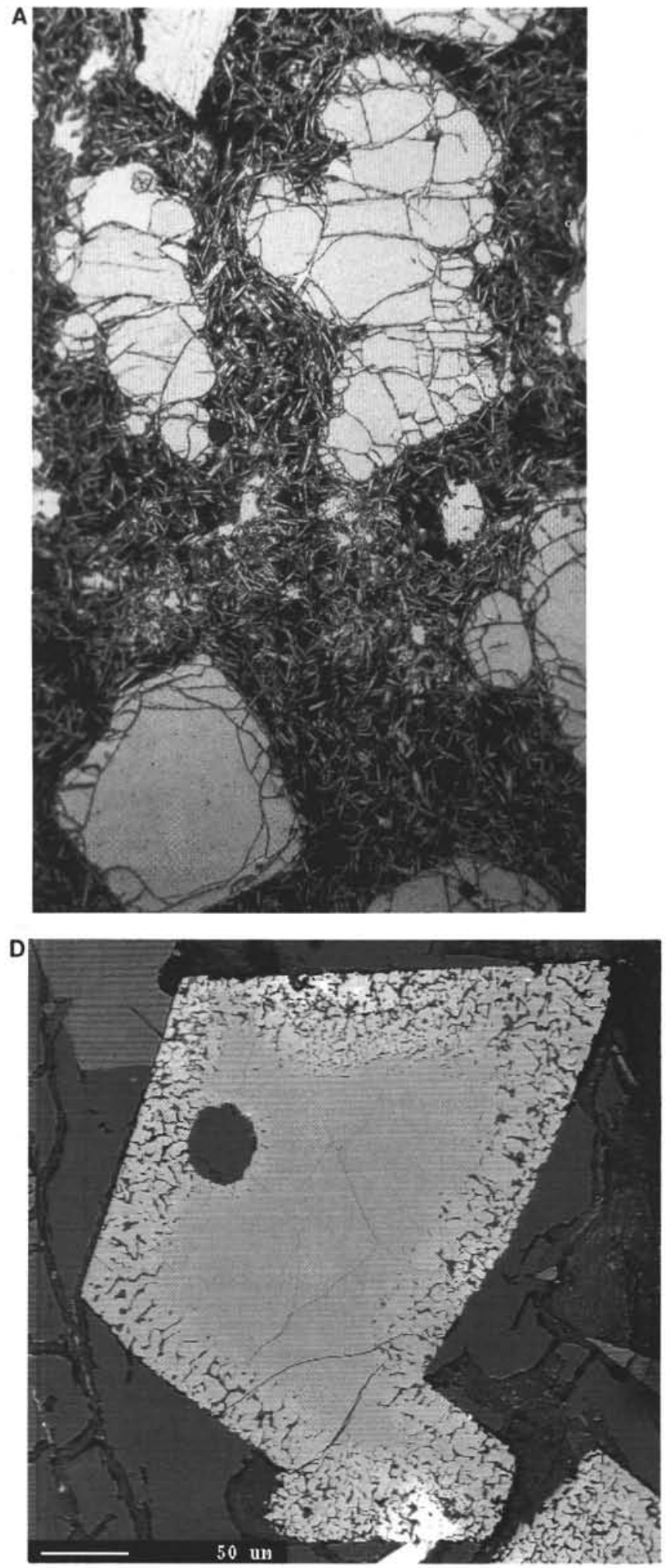
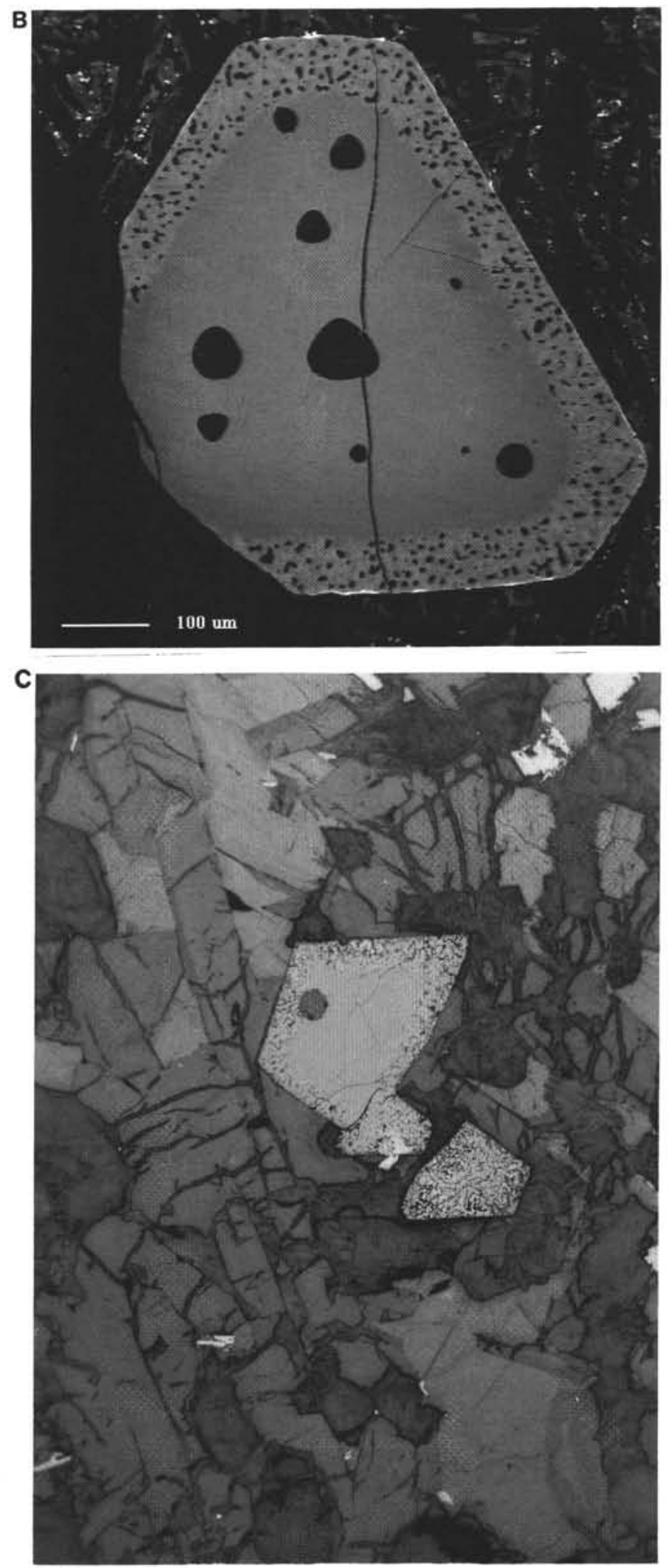

Plate 1. A. Photomicrograph (7 mm across, in transmitted light) of picritic basalt Sample 147-894D-1R-CC, 4-6 cm. Note the abundance of olivine, lying in a quenched, microlitic groundmass. B. Backscattered electron (BSE) image of a large, groundmass spinel in Sample 147-894D-IR-CC, 4-6 cm, exhibiting a resorbed, skeletal ferritchromite rim. The analytical transect of this crystal is shown in Transect $\mathrm{A}$ of Figure 2, with slight internal zoning in $\mathrm{Cr} /\left(\mathrm{Cr}+\mathrm{Al}+\mathrm{Fe}{ }^{3+}\right)$ visible as a darkening in the BSE image. Analyses from this transect are given in Table 1 (Analyses A PC and A PR). C. Reflected light photomicrograph (1.75 $\mathrm{mm}$ across) of Cr-spinel from Sample 147-894G-2R-1, 24-26 cm, showing resorption textures that indicate strong disequilibrium with the late-stage, intergranular melt that produced the coarse intergranular and subophitic groundmass. D. BSE image of the same Cr-spinels in Plate 1C. The resorbed, skeletal, Cr-spinel is made up of ferritchromite, with bright areas on the $\mathrm{Cr}$-spinel margin denoting Ti-rich magnetite. An analytical transect of this grain is shown in Figure 4, with a representative analysis of the $\mathrm{Cr}$-spinel core given in Table 1 (Analysis $5 \mathrm{MC}$ ). 